\title{
31. MANTLE MELTING SYSTEMATICS: TRANSITION FROM CONTINENTAL TO OCEANIC VOLCANISM ON THE SOUTHEAST GREENLAND MARGIN ${ }^{1}$
}

\author{
M.S. Fram, ${ }^{2,3}$ C.E. Lesher, ${ }^{2}$ and A.M. Volpe ${ }^{4}$
}

\begin{abstract}
We present trace element analyses of basaltic and picritic lavas recovered from the Ocean Drilling Program Leg 152 transect on the southeast Greenland volcanic rifted margin. These lavas span the stratigraphic interval from continental to oceanic magmatism. Incompatible element patterns define two geochemical groups within the Site 917 upper series. Group 1 flows are characterized by $(\mathrm{La} / \mathrm{Sm})_{\mathrm{N}}=0.3-0.8$, whereas group 2 flows have $(\mathrm{La} / \mathrm{Sm})_{\mathrm{N}}=0.7-1.2$ and higher mantle-normalized Th, $\mathrm{Ba}$, and $\mathrm{Pb}$, and lower $\mathrm{Nb}$ and $\mathrm{U}$ concentrations. The transition upsection from group 1 to group 2 at Site 917 occurs between 114 and 65 meters below seafloor, and is represented by interfingering of flows belonging to the two groups. $(\mathrm{La} / \mathrm{Sm})_{\mathrm{N}}, \mathrm{Ba} / \mathrm{Zr}$, and $\mathrm{Th} / \mathrm{Pb}$ ratios and mantle-normalized incompatible element concentrations decrease systematically with stratigraphic height within each group, and the Site 915 and Site 918 units are generally continuous with group 2. These variations imply an increase in the extent of partial melting with time. Lu/ $\mathrm{Hf}$ ratios vary from 0.14 to 0.25 through the upper series and into the Site 915 and Site 918 flows. This relationship suggests the importance of residual garnet in the mantle source melting decreased with time. We develop a quantitative model for mantle melting to investigate melting systematics responsible for these relationships. Comparison between observed data and model results suggests a progressive increase in the extent of partial melting (from $4 \%$ to $12 \%$ ) and decrease in mean pressure of melting with time. This temporal evolution of primary magma compositions is explicable by rapid thinning of the continental lithosphere during eruption of the upper series. We conclude that group 1 units were derived from mantle with normal mid-ocean-ridge basalt source characteristics, whereas units from group 2 and from Sites 915 and 918 were derived from a source similar to depleted Icelandic mantle. We infer that the thermal anomaly associated with the ancestral Iceland plume pre-dated the transition in mantle source compositions.
\end{abstract}

\section{INTRODUCTION}

A primary objective of Ocean Drilling Program (ODP) Leg 152 was to characterize the volcanic history associated with continental breakup and the development of the North Atlantic Ocean basin. Fundamental understanding of the conditions of melt generation in the mantle and of the relationship between the erupted products and the ancestral Iceland plume are central to achieving this goal. The southeast Greenland Margin was deemed unique for such studies in view of the well-resolved seaward-dipping reflector sequence (SDRS) present along the continental margin and the remote position of the drilling transect relative to the inferred axis of the plume (Larsen, Saunders, Clift, et al., 1994).

The prevailing working model for early Tertiary magmatism in the North Atlantic relies on the Iceland hot spot (e.g., White et al., 1987; White and McKenzie, 1989; Campbell and Griffiths, 1990; Larsen, Saunders, Clift, et al., 1994). The hot spot is currently a pronounced thermal and chemical anomaly on the Mid-Atlantic Ridge in the immediate vicinity of Iceland, and its influence can be traced south for more than $400 \mathrm{~km}$ along the Reykjanes Ridge (e.g., Schilling and Noe-Nygaard, 1974; Schilling et al., 1983; Klein and Langmuir, 1987). Recent workers (White and McKenzie, 1989; Campbell and Griffiths, 1990) have argued that, in the early Tertiary, the hot spot was a much larger feature, underlying the whole North Atlantic region that experienced volcanism, from West Greenland to the British Isles and along $2000 \mathrm{~km}$ of the East Greenland and conjugate European margins. White and McKenzie (1989), as well as others (Gill

${ }^{1}$ Saunders, A.D., Larsen, H.C., and Wise, S.W., Jr. (Eds.), 1998. Proc. ODP, Sci. Results, 152: College Station, TX (Ocean Drilling Program).

${ }^{2}$ Department of Geology, University of California, Davis, CA 95616, U.S.A

${ }^{3}$ Present address: USGS, 6000 J St., Placer Hall, Sacramento, CA 95819, U.S.A., mfram@usgs.gov

${ }^{4}$ Isotope Sciences Department, Lawrence-Livermore National Laboratory, Livermore, CA 94550, U.S.A. et al., 1992; Larsen et al., 1992), assume that the ancestral Iceland plume axis was situated beneath the Kangerlussuaq area in East Greenland, although a number of models of relative plate motions place the axis 300-500 km to the northwest of that site (Fig. 1; Duncan and Richards, 1991; Lawver and Müller, 1994). However compelling we find the plume models, the role of the ancestral Iceland plume in southeast Greenland Margin volcanism must be critically evaluated by assessing the involvement of thermally and/or compositionally anomalous mantle source regions for the igneous products.

In addition to the consequences of involvement of hot, and possibly compositionally distinct, plume mantle, the volume and composition of primary mantle melts formed by decompression melting during continental breakup are strongly influenced by the overlying continental lithosphere (e.g., McKenzie and Bickle, 1988; Ellam, 1992; Fram and Lesher, 1993; Kerr, 1994). Fram and Lesher (1993) recently showed that differences in composition of primitive magmas for the North Atlantic Tertiary Province are to the first-order related to changes in lithospheric thickness with time. Thick lithosphere impedes mantle upwelling and limits the depth of melt segregation. In areas along the rifted margin, close to the presumed plume axis (i.e., flood basalts of the Blosseville Coast of East Greenland, and Faeroe Islands), the analysis suggested that melting was initiated at depths of 80-100 km within the stability field of garnet lherzolite. Potential temperatures $100^{\circ}-150^{\circ} \mathrm{C}$ above those for the mid-ocean-ridge basalt (MORB) source region were inferred, although the earliest rift products reflect modest $(8 \%-12 \%)$ extents of partial melting. Fram and Lesher (1993) also concluded that the main phase of basaltic volcanism along the Blosseville Coast $\left(68^{\circ}-70^{\circ} \mathrm{N}\right)$ could be derived from a mantle source compositionally similar to that inferred for modern Icelandic basalts. Thirlwall et al. (1994) reached a similar conclusion in their study of basalts from Hold with Hope, thus providing evidence of mantle compositionally similar to Icelandic mantle extending at least as far north as latitude $73.5^{\circ} \mathrm{N}$. The importance of ODP drilling of the southeast Greenland Margin at latitude $63^{\circ} \mathrm{N}$ is the opportunity to characterize lateral and temporal variations of the mantle source at a location even more remote from the plume axis. 
Figure 1. Map of the North Atlantic region at the time of magnetic anomaly 24 (from Larsen, Saunders, Clift, et al., 1994). Points A, B, and C indicate the postulated locations of the axis of the Iceland plume from Duncan (1984), Lawver and Müller (1994), and White and McKenzie (1989), respectively. The locations of onshore and offshore early Tertiary volcanic sequences and drilling transects on the SDRS are also indicated.

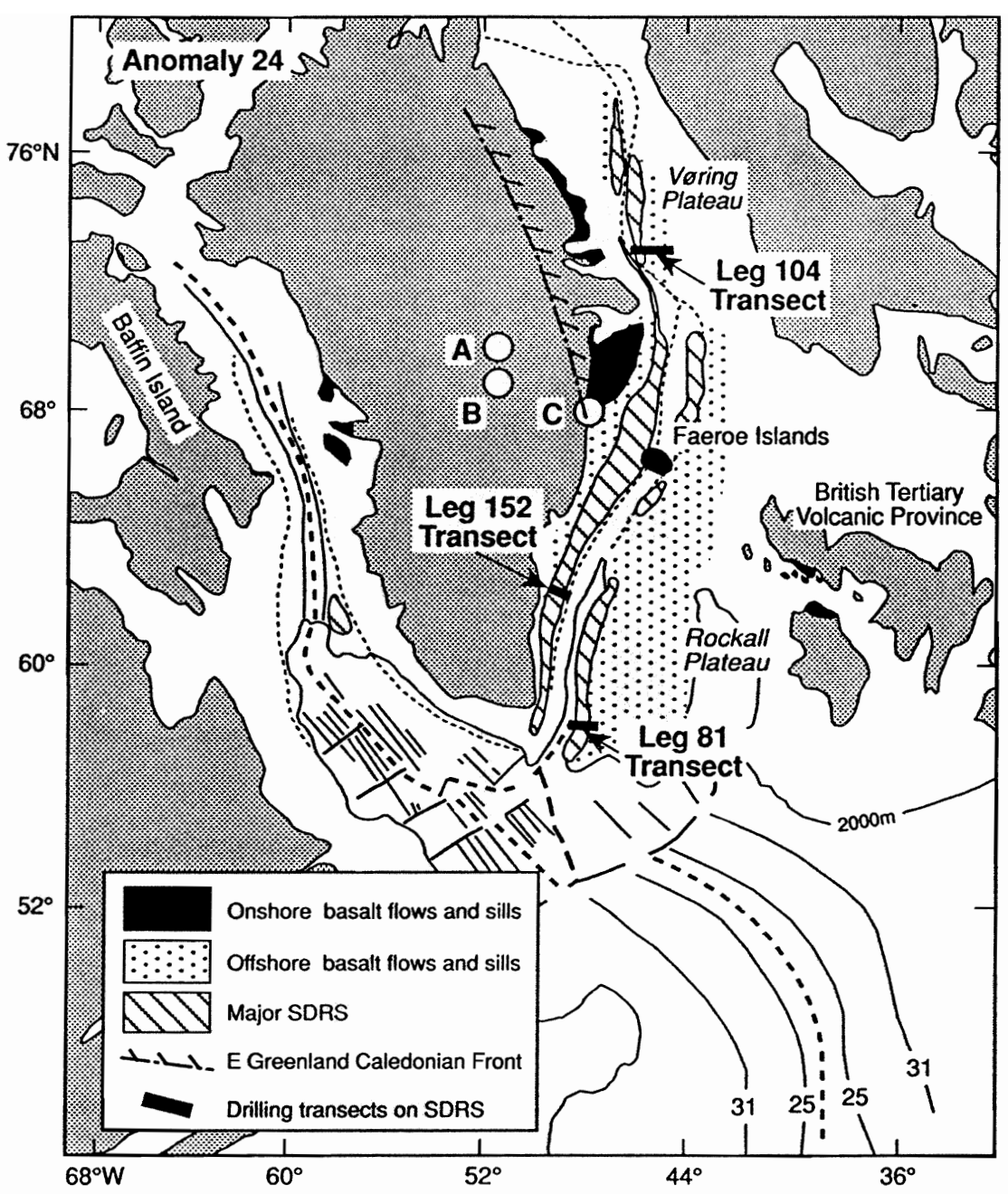

\section{BACKGROUND}

SDRS volcanic rocks were recovered at three drill sites during Leg 152. Hole 917A penetrated $775 \mathrm{~m}$ of the feather edge of the volcanic sequence, reaching underlying continental sediments. The volcanic sequence sampled by Hole $917 \mathrm{~A}$ is divided into three distinct stratigraphic series. The lower series is composed of flows ranging from picrite to basaltic andesite. The middle series is characterized by more differentiated lavas including dacite, while the upper series is dominated by olivine basalt and picrite (Fig. 2A; Shipboard Scientific Party, 1994). Fitton et al. (1995) propose that the lower and middle series represent the pre-breakup succession, reflecting evolution in deep crustal chambers and contamination by continental crust. Emplacement of the upper series lavas marked a change in magmatic style to less restrained passage of magmas through the crust and is believed to correspond to the final stage of breakup and onset of seafloor spreading. Holes 915A and 918D sampled lavas from the main portion of the SDRS. These lavas are compositionally more uniform than lavas from Hole 917A (Fig. 2A). Seismic images indicate that the SDRS volcanic rocks are 5-6 km thick (Larsen and Jakobsdóttir, 1988)

Figure $2 \mathrm{~B}$ shows the variation in $\mathrm{Zr} / \mathrm{Y}$ ratios for basaltic lavas $(\mathrm{MgO}>7 \mathrm{wt} \%)$ of the continental and oceanic succession (Larsen et al., Chap. 27, this volume). Limiting consideration to the least differentiated and least contaminated basalts of the suite reveals important differences between the lower, upper, and oceanic (Sites 915 and 918) series. $\mathrm{Zr} / \mathrm{Y}$ ratios are generally greater than 3 for the lower se- ries and close to 2 for lavas from the oceanic series. A progressive decrease in the $\mathrm{Zr} / \mathrm{Y}$ ratio up section from 3 to 2 is clearly seen within the transitional upper series. Such relationships were noted by the Shipboard Scientific Party (1994) and qualitatively ascribed to changes in mantle source composition and melting systematics with time. The goal of this work is to examine quantitatively this hypothesis using forward modeling of decompression melting. The modeling examines the effects of restriction of mantle upwelling by the continental lithosphere, changes in mantle potential temperature, and differences in source mantle composition on the trace element composition of the partial melts produced. We compare these results with the high-resolution trace element record obtained by inductively coupled plasma mass spectrometry (ICP-MS) for lavas of the upper series at Site 917 and from Sites 915 and 918 representing the transition from continental to oceanic volcanism. The studies by Fitton et al. (Chap. 28, this volume) and Larsen et al. (Chap. 27, this volume) are complementary to the present work and provide more detailed discussions of field relations and major element compositions of the Leg 152 volcanic rocks that are important for a comprehensive understanding of the volcanic history of the southeast Greenland Margin.

\section{ANALYTICAL METHODS}

The samples consisted of 4-cm sections cut from the cores while on board the JOIDES Resolution. The samples were broken into small chips using a hammer. The chips were washed in deionized wa- 

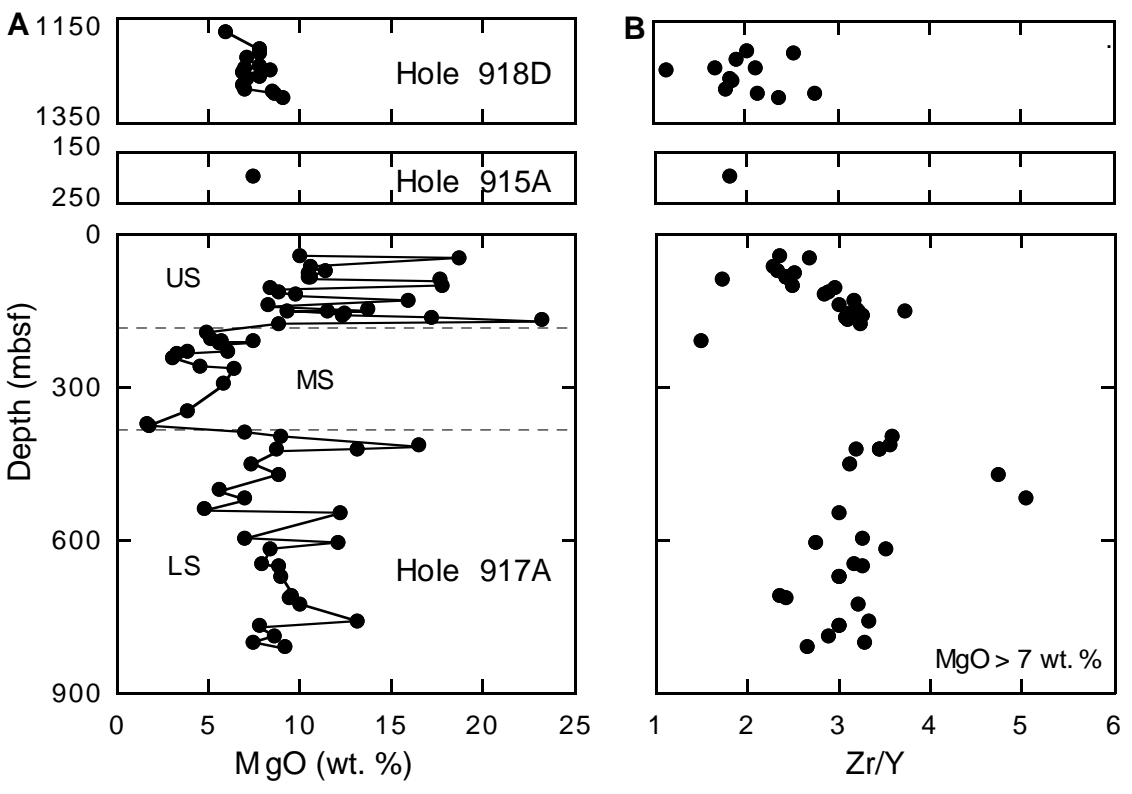

Figure 2. Stratigraphic variation of (A) weight percent $\mathrm{MgO}$ and $(\mathbf{B}) \mathrm{Zr} / \mathrm{Y}$ in lavas from Holes $917 \mathrm{~A}, 915 \mathrm{~A}$, and $918 \mathrm{D}$. The estimated stratigraphic gap between the top of Hole 917A and the base of Hole 915A is $200 \mathrm{~m}$, and Hole 918D is near the center of the SDRS, $>100 \mathrm{~km}$ offshore from Hole 915A (Larsen, Saunders, Clift, et al., 1994). Geochemical data from Larsen et al. (Chap. 27, this volume). In (A) lines connect sequential analyzed flows, although there are occasionally intervening, unanalyzed units. In (B), only the $\mathrm{Zr} / \mathrm{Y}$ of samples with $\mathrm{MgO}>7 \mathrm{wt} \%$ have been plotted. ter, dried thoroughly, and then sorted to remove pieces with saw or hammer marks, secondary veins or vesicle fillings, or other blemishes. The chips were powdered in an alumina shatterbox for 8-15 min. The shatterbox was "pre-contaminated" by powdering and discarding a small amount of sample before powdering the rest of the sample, and cleaned by processing quartz sand between each sample.

All sample dissolutions were undertaken in the clean laboratory facilities at Lawrence-Livermore National Laboratory (LLNL) using the technique outlined by Jenner et al. (1990). We dissolved $100 \mathrm{mg}$ of sample in $10 \mathrm{~mL}$ of $3: 1:: \mathrm{HNO}_{3}: \mathrm{HF}$ (Seastar grade high purity acids) in sealed Teflon beakers at temperatures up to $180^{\circ}$ for $8-48 \mathrm{hr}$. Dissolution was greatly facilitated by immersing the sealed beakers in an ultrasonic bath for 1-4 hr. The samples dissolved completely, except for grains of chromian spinel found in a few flows from the base of the Site 917 upper series. Ionov et al. (1992) encountered the same problem in their study of peridotite standards and determined that incomplete dissolution of spinel does not bias the ICP-MS analyses for elements incompatible in spinel. The modal proportion of spinel in the Leg 152 samples is less than $0.1 \%$, which is significantly smaller than the $1 \%-3 \%$ in the peridotite standards. Experimentally determined partition coefficients for $\mathrm{Ta}, \mathrm{Nb}$, and $\mathrm{Zr}$ between spinel and basaltic liquids are approximately equal to 1 ; those for all the other elements analyzed in this study are less than 0.05 (Green, 1994). Thus, incomplete dissolution of spinel in the Leg 152 samples could result in underestimation of the whole rock concentrations of $\mathrm{Ta}, \mathrm{Nb}$, and $\mathrm{Zr}$ by a maximum of $1 \%$.

The solutions were dried down to volatilize $\mathrm{SiF}_{4}$ and then reconstituted several times in $\mathrm{HNO}_{3}$ to ensure complete transformation of fluorides to nitrates. The samples were then dissolved in $100 \mathrm{~g}$ of $3 \%$ $\mathrm{HNO}_{3}$. One drop of $\mathrm{HF}$ was added to enhance solution stability (Hall et al., 1990). Nineteen milliliters of this dilute solution and $1 \mathrm{~mL}$ of a spike solution containing $2 \mu \mathrm{g}$ of the internal standards ${ }^{115} \mathrm{In}$ and ${ }^{205} \mathrm{Tl}$ were mixed to produce the final sample solutions.

All of the analyses were performed using the VG PlasmaQuad-2 ICP-MS at LLNL. We calculated elemental abundances using measured concentrations of the following isotopes: ${ }^{85} \mathrm{Rb},{ }^{88} \mathrm{Sr},{ }^{89} \mathrm{Y},{ }^{90} \mathrm{Zr}$, ${ }^{93} \mathrm{Nb},{ }^{138} \mathrm{Ba},{ }^{139} \mathrm{La},{ }^{140} \mathrm{Ce},{ }^{146} \mathrm{Nd},{ }^{147} \mathrm{Sm},{ }^{151} \mathrm{Eu},{ }^{157} \mathrm{Gd},{ }^{163} \mathrm{Dy},{ }^{166} \mathrm{Er},{ }^{174} \mathrm{Yb}$, ${ }^{175} \mathrm{Lu},{ }^{178} \mathrm{Hf},{ }^{181} \mathrm{Ta},{ }^{208} \mathrm{~Pb},{ }^{232} \mathrm{Th}$, and ${ }^{238} \mathrm{U}$. These isotopes were chosen because they minimize isobaric interferences; note that they are not necessarily the most abundant isotope for each element. Interferences of oxides of $\mathrm{La}, \mathrm{Ce}$, and $\mathrm{Ba}$ on the middle and heavy rare-earth elements were not a problem due to the machine run conditions and the light-rare-earth-element- (LREE-) and Ba-depleted nature of all the samples. Despite the use of highly dilute solutions $(<0.1 \%$ total dissolved solids), it was necessary to clean the cones thoroughly between runs (i.e., after every 10-15 samples); otherwise noticeable degradation of the signal occurred.

Multi-element standards containing all the elements at concentrations of $0.5,5.0$, and $50 \mathrm{ppb}$ and a solution blank were used to construct the standard curves. The multi-element standard solutions were prepared gravimetrically from Spex single element standard solutions. $\mathrm{U}, \mathrm{Th}$, and $\mathrm{Pb}$ concentrations in the standard solutions were also checked by isotope dilution analysis. The resulting standard curves were nearly linear, although a quadratic term was used in a few cases where it provided a substantially better fit to the standards. The concentrations of elements in the final sample solutions were within the range of concentrations in the standard solutions, except for higher levels of $\mathrm{Sr}, \mathrm{Ba}$, and $\mathrm{Zr}$ in selected samples. A test of linearity of the standard curves was made by re-analyzing several of these samples with standard curves that included an additional standard solution with $250 \mathrm{ppb}$ of each element. The results obtained using these standard curves were identical to the previous results.

The internal standards ${ }^{115} \mathrm{In}$ and ${ }^{205} \mathrm{Tl}$ were present in the multielement standard, blank, and sample solutions at the same concentration of $100 \mathrm{ppb}$. We used these two internal standards to correct for instrumental drift.

Table 1 shows values obtained for USGS basalt standards BIR-1 and BCR-1, both analyzed as unknowns. The average BIR-1 values represent nine analyses of solutions from four separate dissolutions, and the BCR-1 values represent two analyses of solutions from two separate dissolutions. As shown in Table 1, the values obtained in this study compare very well with the accepted values reported in the literature. The analytical precision is also very high, as indicated by the low standard deviation for replicate analyses (Table 1). Yttrium concentrations, however, may be systematically low by $6 \%$. Concentrations of all elements in a full procedural blank were insignificant compared with concentrations in the samples. Multiple analyses for samples representing separate dissolutions demonstrate the high reproducibility of the analytical procedure.

\section{RESULTS}

Table 2 presents the analytical results for all analyzable flows from the Site 917 upper series (total of 22 units), Unit 1 from Site 915, and a representative lava from Site 918 (Unit 8b). The strati- 
Table 1. Analyses of USGS basalt standards BCR-1 and BIR-1 (concentrations in $\mu \mathrm{g} / \mathrm{g}$ ).

\begin{tabular}{cccccccc}
\hline & $\begin{array}{c}\text { BCR-1 } \\
\text { ICP-MS } \\
\mathrm{n}=2\end{array}$ & $\begin{array}{c}\text { Standard } \\
\text { deviation }\end{array}$ & $\begin{array}{c}\text { BCR-1 } \\
\text { compiled }^{\text {values }}\end{array}$ & $\begin{array}{c}\text { BCR-1 } \\
\text { ICP-MS } \\
\text { literature }\end{array}$ & $\begin{array}{c}\text { BIR-1 } \\
\text { ICP-MS } \\
\text { n=9 }\end{array}$ & $\begin{array}{c}\text { Standard } \\
\text { deviation }\end{array}$ & $\begin{array}{c}\text { BIR-1 } \\
\text { accepted } \\
\text { values }^{\mathrm{d}}\end{array}$ \\
\hline $\mathrm{Rb}$ & 47.6 & $(0.1)$ & 47.2 & 46 & 0.18 & $(0.05)$ & 0.24 \\
$\mathrm{Sr}$ & 331 & $(1.0)$ & 330 & 332 & 111 & $(6.0)$ & 110 \\
$\mathrm{Y}$ & 34.2 & $(0.1)$ & 38 & 35.7 & 14.5 & $(0.6)$ & 15.5 \\
$\mathrm{Zr}$ & 189 & $(0.0)$ & 190 & 204 & 15.5 & $(0.6)$ & 15.4 \\
$\mathrm{Nb}$ & 11.6 & $(0.1)$ & 14 & 12.5 & 0.61 & $(0.15)$ & 0.5 \\
$\mathrm{Ba}$ & 647 & $(6.0)$ & 681 & 666 & 6.2 & $(0.3)$ & 7.1 \\
$\mathrm{La}$ & 23.9 & $(0.6)$ & 24.9 & 24.3 & 0.59 & $(0.03)$ & 0.61 \\
$\mathrm{Ce}$ & 52.1 & $(0.9)$ & 53.7 & 52.22 & 1.93 & $(0.09)$ & 1.95 \\
$\mathrm{Nd}$ & 28.7 & $(0.6)$ & 28.8 & 28.1 & 2.28 & $(0.14)$ & 2.34 \\
$\mathrm{Sm}$ & 6.61 & $(0.06)$ & 6.59 & 6.3 & 1.03 & $(0.11)$ & 1.1 \\
$\mathrm{Eu}$ & 2.02 & $(0.01)$ & 1.95 & 2.03 & 0.51 & $(0.04)$ & 0.52 \\
$\mathrm{Gd}$ & 7.60 & $(0.20)$ & 6.68 & 6.9 & 1.84 & $(0.12)$ & 1.84 \\
$\mathrm{Dy}$ & 6.84 & $(0.14)$ & 6.34 & 6.7 & 2.47 & $(0.12)$ & 2.51 \\
$\mathrm{Er}$ & 4.00 & $(0.10)$ & 3.63 & 3.57 & 1.67 & $(0.10)$ & 1.66 \\
$\mathrm{Yb}$ & 3.52 & $(0.03)$ & 3.38 & 3.34 & 1.60 & $(0.07)$ & 1.63 \\
$\mathrm{Lu}$ & 0.52 & $(0.01)$ & 0.51 & 0.5 & 0.24 & $(0.02)$ & 0.25 \\
$\mathrm{Hf}$ & 5.00 & $(0.12)$ & 4.95 & 5.1 & 0.56 & $(0.04)$ & 0.51 \\
$\mathrm{Ta}$ & 0.91 & $(0.21)$ & 0.81 & 0.8 & 0.05 & $(0.01)$ & 0.03 \\
$\mathrm{~Pb}$ & 13.57 & $(0.32)$ & 13.6 & 13.8 & 3.23 & $(0.10)$ & 2.94 \\
$\mathrm{Th}$ & 6.93 & $(0.17)$ & 5.98 & 5.9 & 0.032 & $(0.013)$ & 0.031 \\
$\mathrm{U}$ & 2.04 & $(0.05)$ & 1.75 & 1.7 & 0.017 & $(0.005)$ & 0.0097 \\
\hline
\end{tabular}

\footnotetext{
${ }^{a}$ Gladney and Roelandts (1988) reported in Jenner et al. (1990).

${ }^{\mathrm{b}}$ Jenner et al. (1990).

${ }^{\mathrm{c}}$ Nine replicates for all elements except $\mathrm{U}(\mathrm{n}=7)$ and $\mathrm{Ta}(\mathrm{n}=3)$.

d Jochum et al. (1994).
}

graphic relations for the $\mathrm{Lu} / \mathrm{Hf}, \mathrm{Th} / \mathrm{Pb}, \mathrm{Ba} / \mathrm{Zr}$, and $(\mathrm{La} / \mathrm{Sm})_{\mathrm{N}}$ ratios are shown in Figure 3. Lu/Hf varies from 0.13 at the base of the upper series to greater than 0.25 in the Sites 915 and 918 units. This trend is antithetic to the trend for $\mathrm{Zr} / \mathrm{Y}$ shown in Figure $2 \mathrm{~B}$ and is consistent with the expectation that $\mathrm{Lu}$ (true also for $\mathrm{Y}$ ) is significantly more compatible in garnet than $\mathrm{Hf}$ (and $\mathrm{Zr}$ ). The regular increase in the $\mathrm{Lu} /$ $\mathrm{Hf}$ ratio with stratigraphic height can be attributed to a decrease in the proportion of residual garnet in the mantle source region with time.

There are also important variations in the ratios of incompatible elements that are not strongly affected by the presence of garnet, but sensitive to the extent of melting. For the $(\mathrm{La} / \mathrm{Sm})_{\mathrm{N}}$ ratio, two subparallel arrays are clearly evident when plotted against stratigraphic height (Fig. 3). The majority of units of the upper series form a negatively sloping array with the lowest $(\mathrm{La} / \mathrm{Sm})_{\mathrm{N}}$ ratios $(\sim 0.4)$ represented by the units recovered between 50 and $100 \mathrm{mbsf}$ and highest values (0.6-0.8) for the units below $150 \mathrm{mbsf}$. A second group is offset to higher $(\mathrm{La} / \mathrm{Sm})_{\mathrm{N}}$ ratios and includes three units from the interval between 100 and $125 \mathrm{mbsf}$, two from above $50 \mathrm{mbsf}$, and lavas from Sites 915 and 918 . The $(\mathrm{La} / \mathrm{Sm})_{\mathrm{N}}$ ratio for group two decreases upsection from 1.2 to 0.75 (Fig. 3). Differences between these two groups of flows are also shown by the variations in $\mathrm{Th} / \mathrm{Pb}$ and $\mathrm{Ba} / \mathrm{Zr}$ ratios, with an indication of interfingering of the two groups between 60 and 110 mbsf in the upper series at Site 917 (Fig. 3).

We suggest that the variation in trace element ratios within each of the two groups is consistent with a progressive increase in the extent of melting with time, and that the difference between the two groups is then due to a difference in mantle source compositions. We believe that variable degrees of partial melting of one mantle source could not produce melts with $(\mathrm{La} / \mathrm{Sm})_{\mathrm{N}}$ ranging from 0.4 to 1.2 because the trace element contents (Table 2) and major element compositions (Larsen et al., Chap. 27, this volume; Fitton et al., Chap. 28, this volume) of these lavas do not exhibit a correspondingly large range. Furthermore, we believe that fairly uniform degrees of melting of a highly variable mantle source is also an unlikely explanation for the observed data, because the highly systematic behavior of $\mathrm{Lu} / \mathrm{Hf}$ is most simply accounted for by variations in extent of melting.

How can we distinguish between the effects of mantle processes and of crustal contamination on trace element ratios, such as $\mathrm{Ba} / \mathrm{Zr}$, in the upper series lavas? Larsen, Saunders, Clift, et al. (1994) and Fitton et al. (1995) show convincingly that crustal contamination of middle and lower series lavas resulted in enrichment of Ba, leading to $\mathrm{Ba} / \mathrm{Zr}$ ratios as high as $7 . \mathrm{Sr}$ and $\mathrm{Nd}$ isotope data (Fitton et al., Chap. 29, this volume) for the lower and middle series indicate that these enrichments on Ba are strongly coupled with decreasing ${ }^{143} \mathrm{Nd} /$ ${ }^{144} \mathrm{Nd}$ ratios, further supporting the suggestion of crustal contamination. However, among the six upper series units analyzed by Fitton et al., there is not a clear correlation between $\mathrm{Sr}$ or $\mathrm{Nd}$ isotopic ratios and $\mathrm{Ba} / \mathrm{Zr}$. Twenty-one units in the upper series have $\mathrm{Ba} / \mathrm{Zr}$ less than 0.8, whereas one, Unit 33 (Sample 152-917A-21R-3, 134-138 cm, Piece 5) has $\mathrm{Ba} / \mathrm{Zr}$ equal to 2.0 (Table 2). The ${ }^{143} \mathrm{Nd} /{ }^{144} \mathrm{Nd}$ of Unit 33 is equivalent to that of samples with $\mathrm{Ba} / \mathrm{Zr}$ less than 0.5 and greater than that of a sample with $\mathrm{Ba} / \mathrm{Zr}$ equal to 0.7 . Based on these observations, we conclude that the variations in $\mathrm{Ba} / \mathrm{Zr}$ (and the other trace element ratios) shown in Figure 3 are not controlled by crustal contamination, and do reflect mantle melting systematics and mantle source composition variations.

The significance of the stratigraphic relationships shown in Figure 3 is twofold. First, there is evidence for a change in mantle source composition within the upper series at Site 917. The uppermost units at Site 917 would appear to be genetically related to the single unit recovered at Site 915 and the lavas of the SDRS drilled at Site 918, thus placing the transition to the oceanic mantle regime before eruption of the Unit 1 at Site 915. Second, extent of melting appears to change progressively with time. We test these hypotheses quantitatively below.

The full trace element patterns of the lavas provide more information about the intragroup variations. Figure 4 shows trace element patterns of the lavas normalized both to primitive mantle composition (Sun and McDonough, 1989) and to primary liquid compositions for the Site 917 lavas. Thy et al. (this volume) and Fitton et al. (Chap. 28, this volume) show that for most of the upper series lavas, the major element composition is controlled to a first-order by addition or subtraction of olivine. All of the elements considered here (see Table 2) are incompatible in olivine and, therefore, the absolute concentrations of these elements are highly variable. We correct for fractional crystallization of olivine by recalculating the whole rock compositions (data from Larsen et al., Chap. 27, this volume) by incremental addition of equilibrium olivine in steps of $0.5 \%$ until the calculated liquid reaches equilibrium with mantle olivine $\left(\mathrm{Fo}_{90}\right)$. We assume $\mathrm{K}_{\mathrm{D}}$ for iron-magnesium exchange between olivine and liquid equals 0.31 (Longhi, 1991). For whole rock compositions that clearly represent accumulations of olivine in liquid, we subtract olivine until the remaining liquid reaches equilibrium with $\mathrm{Fo}_{90}$ olivine. Based on Thy et al. (this volume), we used $\mathrm{Fo}_{84}$ for the accumulated olivine. Incompatible element concentrations in the whole rock compositions were recalculated with a Rayleigh fractionation equation using the extent 
Table 2. ICP-MS analyses of Leg 152 samples (concentrations in $\mu \mathrm{g} / \mathrm{g}$ ).

\begin{tabular}{|c|c|c|c|c|c|c|c|c|c|c|c|c|c|c|}
\hline Hole: & $917 \mathrm{~A}$ & $917 \mathrm{~A}$ & $917 \mathrm{~A}$ & $917 \mathrm{~A}$ & & $917 \mathrm{~A}$ & $917 \mathrm{~A}$ & $917 \mathrm{~A}$ & & & $917 \mathrm{~A}$ & $917 \mathrm{~A}$ & $917 \mathrm{~A}$ & $917 \mathrm{~A}$ \\
\hline Core, section: & 6R-1 & $7 \mathrm{R}-2$ & $9 \mathrm{R}-3$ & $10 \mathrm{R}-1$ & 10R-1 & $10 \mathrm{R}-4$ & 11R-1 & $11 \mathrm{R}-4$ & 11R-4 & 11R-4 & $12 \mathrm{R}-1$ & $13 \mathrm{R}-2$ & 13R-5 & $14 \mathrm{R}-3$ \\
\hline Interval $(\mathrm{cm})$ : & $100-104$ & $4-8$ & $45-49$ & $61-65$ & (replicate) & $40-44$ & $124-128$ & $26-30$ & (replicate) & (replicate) & $26-31$ & $35-38$ & $129-133$ & $68-72$ \\
\hline Piece: & 9 & 1 & 5 & $1 \mathrm{E}$ & & $2 \mathrm{~A}$ & $5 \mathrm{C}$ & $1 \mathrm{~B}$ & & & $4 \mathrm{~A}$ & $1 \mathrm{~B}$ & 11 & $6 \mathrm{~B}$ \\
\hline Depth (mbsf): & 42.7 & 48.21 & 68.06 & 74.51 & & 78.45 & 84.14 & 87.02 & & & 92.26 & 102.9 & 108.28 & 113.33 \\
\hline Unit: & 1 & 2 & 8 & 9 & & 10 & 12 & 13 & & & 14 & 16 & 17 & 18 \\
\hline $\mathrm{Rb}$ & 2.43 & 1.89 & 0.92 & 0.30 & 0.36 & 1.25 & 2.30 & 0.31 & 0.42 & 0.40 & 0.91 & 1.52 & 0.64 & 0.97 \\
\hline $\mathrm{Sr}$ & 162.2 & 70.4 & 116.2 & 134.3 & 132.7 & 122.0 & 156.0 & 124.5 & 123.9 & 123.3 & 41.4 & 214.1 & 146.4 & 154.3 \\
\hline $\mathrm{Y}$ & 20.8 & 12.4 & 19.8 & 20.4 & 20.1 & 19.6 & 21.9 & 20.4 & 20.5 & 20.5 & 16.4 & 17.2 & 25.4 & 23.4 \\
\hline $\mathrm{Zr}$ & 58.4 & 38.7 & 49.7 & 56.5 & 55.4 & 55.8 & 60.5 & 55.0 & 55.7 & 55.9 & 33.4 & 49.3 & 82.5 & 75.7 \\
\hline $\mathrm{Nb}$ & 1.99 & 0.81 & 0.60 & 0.92 & 0.90 & 1.51 & 0.95 & 1.08 & 1.29 & 1.21 & 0.32 & 0.97 & 2.33 & 1.85 \\
\hline $\mathrm{Ba}$ & 32.0 & 17.0 & 24.0 & 5.0 & 5.5 & 14.3 & 16.3 & 5.8 & 5.6 & 5.7 & 4.0 & 24.2 & 59.7 & 60.9 \\
\hline $\mathrm{La}$ & 2.85 & 1.81 & 1.18 & 1.62 & 1.65 & 1.57 & 1.74 & 1.71 & 1.68 & 1.67 & 0.65 & 2.48 & 5.42 & 5.16 \\
\hline $\mathrm{Ce}$ & 8.07 & 5.06 & 4.13 & 5.46 & 5.53 & 5.54 & 5.82 & 5.9 & 5.83 & 5.9 & 2.05 & 6.70 & 14.11 & 12.9 \\
\hline $\mathrm{Nd}$ & 7.24 & 4.03 & 4.66 & 5.55 & 5.56 & 6.14 & 5.97 & 6.12 & 6.28 & 6.29 & 2.60 & 5.14 & 10.87 & 8.78 \\
\hline $\mathrm{Sm}$ & 2.38 & 1.35 & 1.91 & 2.12 & 2.12 & 2.22 & 2.22 & 2.19 & 2.38 & 2.41 & 1.16 & 1.80 & 3.47 & 2.64 \\
\hline $\mathrm{Eu}$ & 1.02 & 0.55 & 0.8 & 0.85 & 0.86 & 1.00 & 0.9 & 0.95 & 1.00 & 0.97 & 0.51 & 0.68 & 1.33 & 0.99 \\
\hline $\mathrm{Gd}$ & 3.82 & 1.94 & 2.92 & 3.12 & 3.11 & 3.60 & 3.32 & 3.47 & 3.54 & 3.58 & 2.05 & 2.47 & 4.86 & 3.69 \\
\hline Dy & 4.04 & 2.14 & 3.36 & 3.41 & 3.51 & 4.11 & 3.65 & 3.74 & 4.26 & 4.11 & 2.63 & 2.86 & 5.16 & 3.87 \\
\hline $\mathrm{Er}$ & 2.49 & 1.19 & 2.08 & 2.06 & 2.01 & 2.50 & 2.17 & 2.26 & 2.54 & 2.45 & 1.64 & 1.71 & 3.02 & 2.27 \\
\hline $\mathrm{Yb}$ & 2.25 & 1.10 & 1.86 & 1.80 & 1.82 & 2.16 & 1.92 & 1.96 & 2.27 & 2.20 & 1.55 & 1.52 & 2.63 & 1.98 \\
\hline $\mathrm{Lu}$ & 0.32 & 0.16 & 0.28 & 0.27 & 0.27 & 0.32 & 0.3 & 0.27 & 0.33 & 0.32 & 0.21 & 0.22 & 0.38 & 0.29 \\
\hline $\mathrm{Hf}$ & 1.85 & 0.95 & 1.34 & 1.47 & 1.43 & 1.77 & 1.55 & 1.57 & 1.76 & 1.73 & 0.89 & 1.31 & 2.65 & 1.94 \\
\hline $\mathrm{Ta}$ & & 0.06 & 0.08 & 0.07 & 0.09 & & 0.07 & & & & 0.16 & 0.07 & 0.11 & 0.16 \\
\hline $\mathrm{Pb}$ & 0.82 & 0.40 & 0.28 & 0.32 & 0.39 & 0.33 & 0.37 & 0.32 & 0.33 & 0.35 & 0.18 & 0.66 & 1.32 & 1.25 \\
\hline Th & 0.288 & 0.178 & 0.061 & 0.104 & 0.111 & 0.094 & 0.109 & 0.094 & 0.089 & 0.084 & 0.107 & 0.403 & 0.620 & 0.687 \\
\hline $\mathrm{U}$ & 0.029 & 0.008 & 0.022 & 0.024 & 0.019 & 0.022 & 0.014 & & & & 0.008 & 0.017 & 0.038 & 0.025 \\
\hline
\end{tabular}

Table 2 (continued).

\begin{tabular}{|c|c|c|c|c|c|c|c|c|c|c|c|c|c|}
\hline Hole: & $917 \mathrm{~A}$ & $917 \mathrm{~A}$ & $917 \mathrm{~A}$ & $917 \mathrm{~A}$ & $917 \mathrm{~A}$ & $917 \mathrm{~A}$ & $917 \mathrm{~A}$ & $917 \mathrm{~A}$ & $917 \mathrm{~A}$ & $917 \mathrm{~A}$ & $917 \mathrm{~A}$ & $915 \mathrm{~A}$ & 918D \\
\hline Core, section: & $15 \mathrm{R}-2$ & $16 \mathrm{R}-3$ & $17 R-4$ & $18 \mathrm{R}-3$ & $18 \mathrm{R}-4$ & $18 \mathrm{R}-6$ & $19 \mathrm{R}-2$ & $19 R-4$ & 20R-1 & $20 \mathrm{R}-4$ & 21R-3 & $24 \mathrm{R}-2$ & $101 \mathrm{R}-4$ \\
\hline Interval $(\mathrm{cm})$ : & $23-28$ & $31-37$ & $87-92$ & 93-97 & $101-105$ & $91-95$ & $51-55$ & $51-55$ & $50-54$ & $135-139$ & $134-138$ & $56-60$ & $83-87$ \\
\hline Piece: & 1B & $1 \mathrm{C}$ & 4 & 2 & 7B & $5 \mathrm{~A}$ & 1B & 3 & 4 & 11 & 5 & 2B & 11 \\
\hline Depth (mbsf): & 120.88 & 131.42 & 141.56 & 149.51 & 151 & 153.85 & 157.21 & 160.1 & 165 & 170.1 & 177.83 & 198.64 & 1226.52 \\
\hline Unit: & 19 & 21 & 24 & 25 & 26 & 27 & 30 & $31 \mathrm{a}$ & $31 \mathrm{~b}$ & $32 b$ & 33 & 1 & $8 b$ \\
\hline $\mathrm{Rb}$ & 0.72 & 1.64 & 3.52 & 1.66 & 1.10 & 3.97 & 2.51 & 6.93 & 5.54 & 2.63 & 7.61 & 3.13 & 0.44 \\
\hline $\mathrm{Sr}$ & 147.0 & 126.2 & 164.4 & 127.7 & 144.7 & 133.8 & 104.5 & 132.8 & 95.5 & 91.2 & 145.7 & 77.9 & 99.4 \\
\hline $\mathrm{Y}$ & 23.2 & 16.7 & 22.5 & 26.1 & 27.9 & 27.2 & 30.5 & 26.6 & 21.0 & 11.3 & 21.4 & 23.7 & 29.7 \\
\hline $\mathrm{Zr}$ & 75.4 & 62.1 & 74.2 & 97.1 & 105.7 & 97.7 & 109.0 & 93.6 & 71.5 & 38.9 & 77.7 & 50.9 & 65.1 \\
\hline $\mathrm{Nb}$ & 1.83 & 1.73 & 1.82 & 3.74 & 3.72 & 3.62 & 3.78 & 3.45 & 2.57 & 1.00 & 2.09 & 1.59 & 2.69 \\
\hline $\mathrm{Ba}$ & 13.0 & 18.9 & 16.7 & 26.7 & 24.9 & 27.3 & 76.6 & 30.8 & 18.5 & 15.3 & 153.7 & 23.3 & 14.9 \\
\hline $\mathrm{La}$ & 2.66 & 2.24 & 2.69 & 4.71 & 4.91 & 4.70 & 5.11 & 4.47 & 3.50 & 1.36 & 3.18 & 2.07 & 2.60 \\
\hline $\mathrm{Ce}$ & 8.73 & 7.47 & 8.77 & 14.28 & 14.81 & 14.43 & 15.45 & 13.2 & 10.21 & 4.35 & 9.84 & 5.53 & 7.17 \\
\hline $\mathrm{Nd}$ & 8.33 & 6.74 & 8.35 & 12.33 & 13.36 & 13.06 & 14.2 & 12.02 & 9.14 & 4.59 & 9.71 & 4.60 & 6.42 \\
\hline $\mathrm{Sm}$ & 2.80 & 2.12 & 2.85 & 3.63 & 4.22 & 4.30 & 4.14 & 3.46 & 2.74 & 1.32 & 3.12 & 1.72 & 2.38 \\
\hline $\mathrm{Eu}$ & 1.05 & 0.82 & 1.10 & 1.40 & 1.60 & 1.54 & 1.66 & 1.38 & 1.03 & 0.54 & 1.29 & 0.68 & 0.87 \\
\hline $\mathrm{Gd}$ & 3.72 & 3.04 & 3.93 & 4.77 & 5.77 & 5.54 & 5.72 & 4.76 & 3.82 & 1.89 & 4.47 & 2.78 & 3.61 \\
\hline Dy & 3.88 & 2.85 & 3.93 & 5.01 & 6.02 & 5.78 & 5.67 & 4.6 & 3.76 & 1.92 & 4.56 & 3.53 & 4.31 \\
\hline $\mathrm{Er}$ & 2.23 & 1.74 & 2.19 & 2.96 & 3.41 & 3.22 & 3.45 & 2.89 & 2.30 & 1.17 & 2.53 & 2.43 & 2.81 \\
\hline $\mathrm{Yb}$ & 1.89 & 1.55 & 1.97 & 2.58 & 2.95 & 2.87 & 2.99 & 2.51 & 2.13 & 1.04 & 2.26 & 2.40 & 2.77 \\
\hline $\mathrm{Lu}$ & 0.28 & 0.21 & 0.27 & 0.37 & 0.43 & 0.41 & 0.41 & 0.34 & 0.26 & 0.14 & 0.33 & 0.36 & 0.42 \\
\hline Hf & 1.90 & 1.65 & 2.00 & 2.75 & 3.23 & 3.06 & 3.18 & 2.67 & 1.94 & 1.07 & 2.36 & 1.27 & 1.64 \\
\hline $\mathrm{Ta}$ & & & 0.14 & & & 0.10 & 0.16 & & & & & & \\
\hline $\mathrm{Pb}$ & 0.56 & 0.45 & 0.49 & 0.71 & 0.81 & 1.57 & 0.76 & 0.72 & 0.54 & 0.22 & 0.50 & 0.41 & 0.30 \\
\hline Th & 0.180 & 0.116 & 0.147 & 0.349 & 0.396 & 0.390 & 0.414 & 0.387 & 0.323 & 0.103 & 0.211 & 0.253 & 0.236 \\
\hline $\mathrm{U}$ & 0.030 & & 0.038 & 0.016 & 0.088 & 0.056 & 0.087 & 0.048 & 0.034 & 0.025 & 0.049 & 0.062 & 0.069 \\
\hline
\end{tabular}

of fractionation or accumulation required for the corrections above. These fractionation/accumulation-corrected liquid compositions are our estimates of the primary liquid compositions parental to the lavas. The normalization to primitive mantle (Sun and McDonough, 1989) further reveals relationships to possible source mantle and also to relative extent of melting. The elements in the diagrams in Figure 4 are arranged from left to right in order of increasing compatibility inferred during mantle melting (e.g., Sun and McDonough, 1989).

Figures 4A and 4B show the fractionation/accumulation-corrected mantle-normalized incompatible element patterns of units from group 1 of the Site 917 upper series. The patterns are generally coherent except for the deviations occasionally shown by $\mathrm{Rb}, \mathrm{Ba}, \mathrm{U}$, and $\mathrm{Pb}$. These deviations are likely due to mobility of these elements during alteration of the lava flows. In addition, Fitton et al. (Chap. 28, this volume) and Larsen et al. (Chap. 27, this volume) show that crustal contamination of the Leg 152 lavas is accompanied by enrichment in $\mathrm{Rb}$ and $\mathrm{Ba}$, although, as discussed above, such contamination is negligible in upper series units and only clearly apparent in Unit 33 (Fig. 4B).

Figures $4 \mathrm{~A}$ and $4 \mathrm{~B}$ indicate a clear stratigraphic progression in mantle-normalized incompatible element patterns within the Site 917 upper series group 1 fractionation/accumulation-corrected liquids. Units from the bottom portion of the upper series (Units 25, 26, 27, $30,31 \mathrm{~A}$ ) all have similar patterns and have the highest fractionation/ accumulation-corrected concentrations for all the elements considered (Fig. 4A). The stratigraphically highest units, Units 9, 10, 12, and 13 , have nearly coincident patterns and lower normalized concentrations for all the elements (Fig. 4B). Units 19, 21, and 24 have fractionation/accumulation-corrected concentrations that are intermediate between those of the stratigraphically higher and lower units (Fig. 4B). These relationships are consistent with an increase in the extent of partial melting with time (higher extents of melting result in primary liquids with lower concentrations of incompatible elements by dilution).

The stratigraphic variations in trace element ratios (Fig. 3) imply that the slopes of the full trace element patterns should also change progressively. The difference in concentrations is greatest for the most highly incompatible elements (Rb, Ba, Th, U, Nb, and La) (Fig. 4A, B). Fractionation between these elements, and hence their relative enrichment, occurs most effectively at lower extents of melting. As the extent of melting increases, the incompatible element patterns of the melts approach that of the source mantle. The low concentra- 

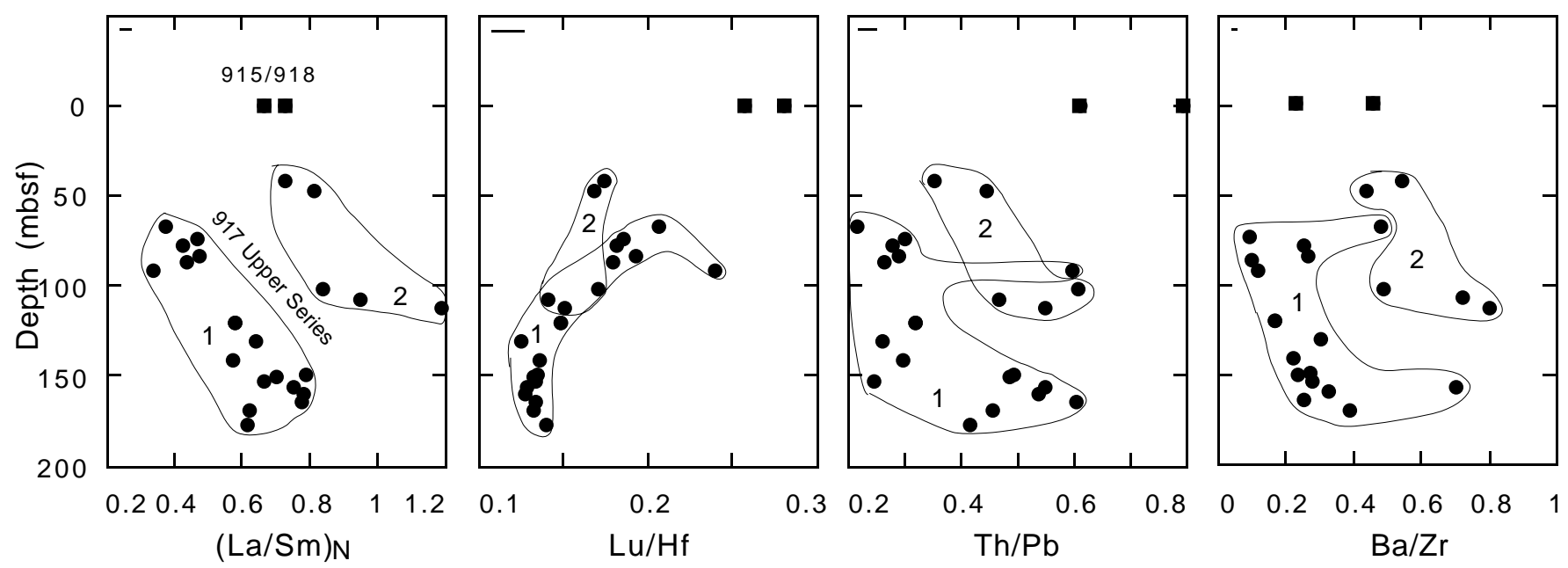

Figure 3. Stratigraphic variation of $\mathrm{Lu} / \mathrm{Hf}, \mathrm{Th} / \mathrm{Pb}, \mathrm{Ba} / \mathrm{Zr}$, and $(\mathrm{La} / \mathrm{Sm})_{\mathrm{N}}$. Site 917 samples are plotted vs. depth and Sites 915 and 918 samples are arbitrarily plotted at 0 mbsf. Site 917 samples are divided into two geochemical groups based on (La/Sm) $)_{\mathrm{N}}$ relations. Unit 33 (Sample 152-917A-21R-3, 134-138 cm, Piece 5) is omitted from the $\mathrm{Ba} / \mathrm{Zr}$ panel because $\mathrm{Ba} / \mathrm{Zr}=2.0$ (Table 2). Average error bars are shown in the upper left corner of each panel.

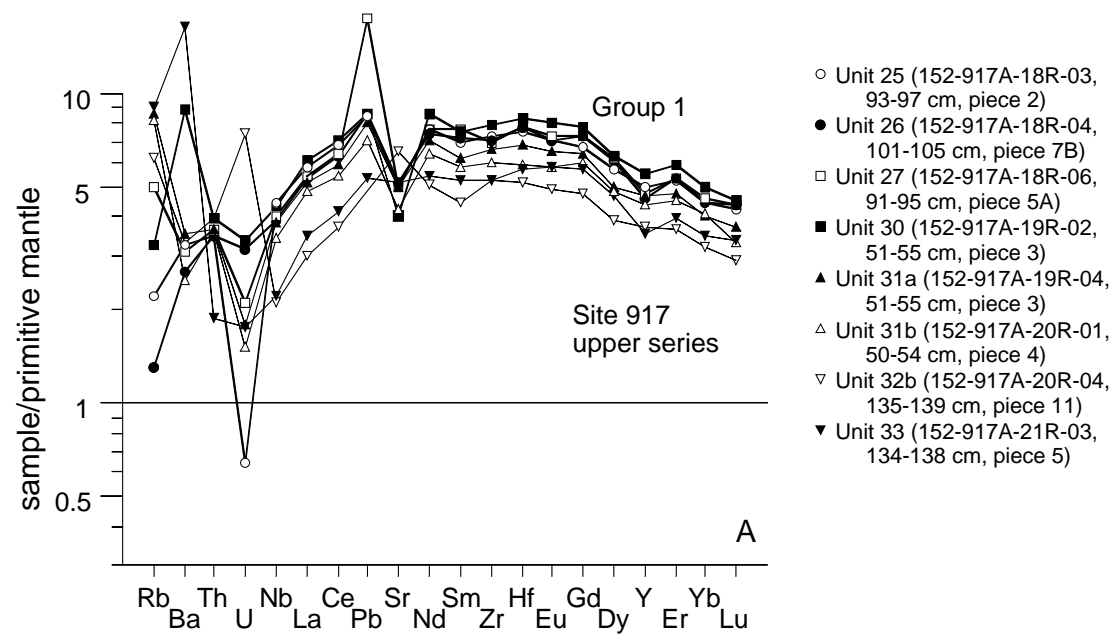

Figure 4. Incompatible element contents of Site 917A upper series (A, B, and C) and Sites 915 and 918 (D) samples normalized to primitive mantle (Sun and McDonough, 1989) and to primary liquid composition. Whole rock compositions are corrected for olivine fractionation or accumulation to equilibrium with mantle olivine $\left(\mathrm{Fo}_{90}\right)$. See text for further discussion. (A) and (B) show Site 917 upper series samples from group 1 (see discussion of Fig. 3), and the division into two figures is by stratigraphic position. (C) shows Site 917 upper series samples from group 2. (D) shows Site 915 and Site 918 samples. Diagram produced using software of Wheatley and Rock (1988).

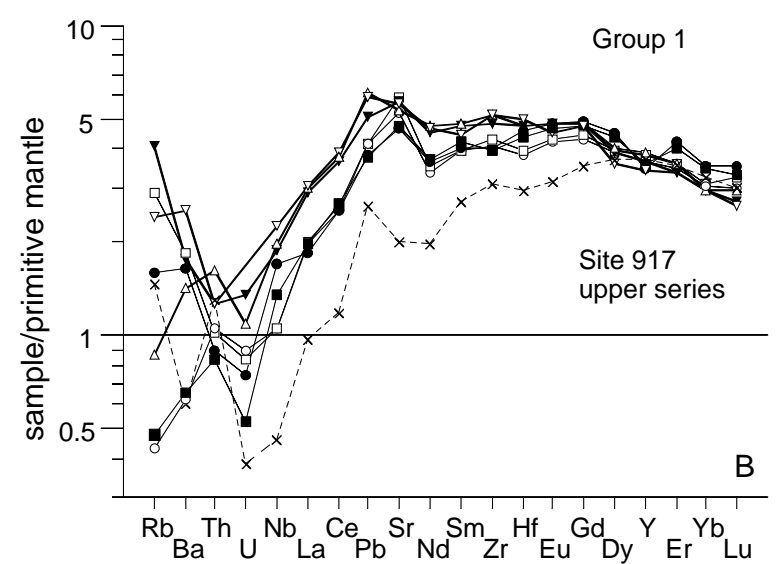

- Unit 9 (152-917A-10R-01, $61-65 \mathrm{~cm}$, piece $1 \mathrm{E})$

- Unit 10 (152-917A-10R-04 $40-44 \mathrm{~cm}$, piece $2 \mathrm{~A}$

- Unit 12 (152-917A-11R-01, $124-128 \mathrm{~cm}$, piece $5 \mathrm{C})$

- Unit 13 (152-917A-11R-04 $26-30 \mathrm{~cm}$, piece $1 \mathrm{~B})$

$\times$ Unit $14(152-917 \mathrm{~A}-12 \mathrm{R}-01$, $26-31 \mathrm{~cm}$, piece $4 \mathrm{~A})$

$\triangle$ Unit 19 (152-917A-15R-02, $23-28 \mathrm{~cm}$, piece $1 \mathrm{~B})$

$\nabla$ Unit 21 (152-917A-16R-03, $31-37 \mathrm{~cm}$, piece $1 \mathrm{C})$

$\checkmark$ Unit 24 (152-917A-17R-04, $87-92 \mathrm{~cm}$, piece 4) 

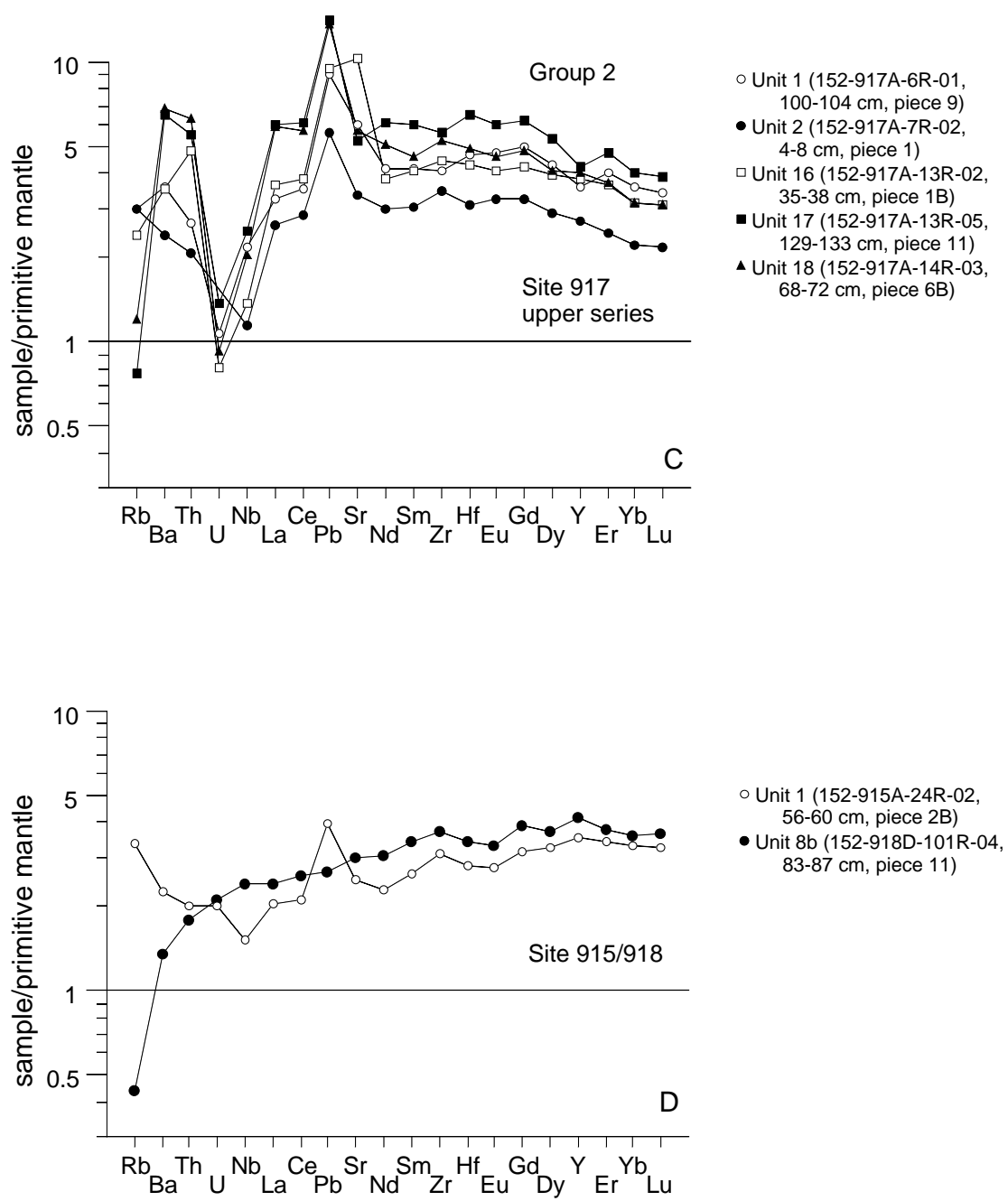

Figure 4 (continued).

tions of the most incompatible elements (i.e., $\mathrm{Rb}, \mathrm{Ba}, \mathrm{Th}, \mathrm{U}$, and $\mathrm{Nb}$ ) in the fractionation/accumulation-corrected lavas compared to primitive mantle indicate that the mantle source for the Site 917 magmas must be depleted relative to primitive mantle.

The relationship among $\mathrm{Sr}, \mathrm{Pb}$, and the LREEs provides another example of progressive changes in the mantle-normalized element patterns. The basal units show a negative $\mathrm{Sr}$ anomaly as compared with $\mathrm{Pb}$ and $\mathrm{Nd}$ (Fig. 4A), while the middle units have a smooth slope through $\mathrm{Pb}, \mathrm{Sr}$, and $\mathrm{Nd}$, and the top units show a slight positive $\mathrm{Sr}$ anomaly (Fig. 4B). This may suggest increasing incompatibility of $\mathrm{Sr}$ relative to $\mathrm{Pb}$ and $\mathrm{Nd}$ as extent of melting increases.

Although $(\mathrm{La} / \mathrm{Sm})_{\mathrm{N}}$ relationships (Fig. 3) indicate that Unit 14 is also in group 1, the trace element pattern for its estimated primary liquid displays a significantly different shape compared with those of the other group 1 units (Fig. 4B). The $\mathrm{FeO}$ and $\mathrm{MgO}$ contents of Unit 14 are appropriate for an upper series primary magma, but other features of the major element composition indicate that it is distinct from the others (Thy et al., this volume). Petrographic examination of Unit 14 reveals that it is unique among the upper series lavas in that it contains olivine and orthopyroxene microphenocrysts (Lesher and Fram, unpubl. data).

Units from group 2 (Fig. 3) display slightly different incompatible element patterns compared to those from group 1. Although the overall fractionation/accumulation-corrected concentrations in group 2 samples (Units 1, 2, 16, 17, and 18) are similar to those in group 1, these five units have systematically higher contents of $\mathrm{Th}, \mathrm{Ba}$, and $\mathrm{Pb}$ and lower $\mathrm{Nb}, \mathrm{U}$, and $\mathrm{Rb}$, which significantly alters the shape of the pattern (compare Fig. 4C with Figs. 4A and B). Such a change in the shape of the pattern without a corresponding change in the overall concentrations cannot be produced solely by a shift in the conditions of melting and requires involvement of mantle of a slightly different composition. In addition, within the five units in Figure 4C, there is a stratigraphic progression in incompatible element patterns similar to that seen within group 1 (Fig. 4A, B). The stratigraphically lowest units (Units 17,18) have the highest concentrations, while the stratigraphically higher units (Units 1 and 2) have lower concentrations of all elements except $\mathrm{Rb}$ and $\mathrm{U}$. Concentrations in Unit 16 are generally intermediate. This relationship is consistent with generation of the primary liquids by an increasing extent of partial melting with time, as concluded from consideration of the group 1 calculation primary liquid compositions.

Fractionation/accumulation-corrected incompatible element concentrations for igneous units from Sites 915 and 918 are lower than the concentrations in all the Site 917 units except for the stratigraphically highest ones (Units 1 and 2) (Fig. 4D). To a first order, this suggests that primary liquids for the Sites 915 and 918 lavas were produced by relatively high extents of partial melting as were the primary liquids for the stratigraphically highest Site 917 units. However, there is a distinction between the mantle-normalized trace element patterns of the Site 917 upper series group 2 and the Sites 915 and 918 fractionation/accumulation-corrected liquids. The calculated primary liquids for the Sites 915 and 918 units have higher relative concentrations of the heavy rare-earth elements (HREE) and $\mathrm{Y}$ than do those for the Site 917 units, resulting in a crossing of the patterns (Fig. 4C, 
D). This crossing of the patterns indicates a marked decrease in the role of residual garnet during mantle melting between generation of the Site 917 and Sites 915 and 918 primary liquids.

In addition, there are also subtle, but important, differences between the mantle-normalized patterns for the Site 915 and the Site 918 calculated parental liquids. The Site 915 liquid shows a relative depletion in $\mathrm{Nb}$ and enrichment in $\mathrm{Pb}$ compared with the Site 918 liquid (Fig. 4D). These enrichments and depletions in the Site 915 liquid are similar to those observed in the Site 917 upper series group 2 liquids (Fig. 4C), but smaller in magnitude. The incompatible element characteristics of the Site 915 calculated primary liquid appear transitional between those of the Site 917 upper series group 2 and the Site 918 calculated primary liquids.

\section{DISCUSSION}

\section{Trace Element Systematics for Decompression Melting}

The stratigraphic variations in trace element contents and ratios shown in Figures 3 and 4 are indicative of variable extents of mantle melting involving at least two distinct source compositions. Evidence for a transition from the continental to oceanic mantle regime is found in the upper series and is defined by a stratigraphic progression toward lower incompatible element contents (Fig. 4) and lower La/ $\mathrm{Sm}$ and $\mathrm{Ba} / \mathrm{Zr}$ ratios (Fig. 3), suggesting an increase in the extent of partial melting. This observation, coupled with the increase in $\mathrm{Lu} / \mathrm{Hf}$ (Fig. 3) and decrease in $\mathrm{Zr} / \mathrm{Y}$ (Fig. 2B) upsection, implies an increase in the proportion of melting at pressures less than the $20 \mathrm{kbar}$ needed for garnet stability. This interpretation of the trace element systematics is consistent with rapid attenuation of the continental lithosphere accompanied by decompression of anomalously hot mantle. What seems important is that the continental lithosphere apparently restricted upwelling at the early stages of breakup, even though the potential temperature of the underlying mantle was already elevated. An interesting aspect of mantle dynamics during the breakup phase along the southeast Greenland Margin is the evidence shown in Figure 3 for involvement of a second mantle component late in the construction of the upper series succession. Below we explore in more quantitative fashion the effects of lithospheric thinning, potential temperature, and mantle composition on the generation and the composition of primary mantle melts.

\section{A Melting Model}

We model mantle melting using the approach of Fram and Lesher (1993). The modeling is performed with the FORTRAN program, REEBOX (Fram, 1994; Fram and Lesher, 1993). The program calculates trace element contents of melts produced by partial melting during passive upwelling of the mantle. The path of mantle parcels through the melting zone is assumed to be governed by simple corner flow (see Fig. 5). Mantle enters the base of the melting zone, melts while ascending over a specified interval, and ceases melting when it begins to move horizontally. Parcels in the center ascend the farthest and so melt to the greatest extent. Hotter mantle begins melting deeper because it intersects its solidus at higher pressure. Decompression of mantle is limited to beneath the mechanical lithosphere and once flow is horizontal, melting ceases. Thus, the starting pressure for the partial melting calculation is a proxy for mantle temperature, and the pressure of final melt extraction is a measure of lithospheric thickness. Melting confined beneath a thick lithosphere occurs at high mean pressures and to low mean extents of melting. As the lithosphere thins, the mean pressure of melting decreases and the mean extent of melting increases (Fig. 5).

Melting is assumed to be a polybaric, largely fractional fusion process (e.g., Longhi, 1991). The percent of partial melting for each $1 \mathrm{kbar}$ of decompression of the mantle is taken to be $1.5 \%$ (Langmuir et al., 1992). Melting proceeds by incremental non-modal batch equi-
A

B
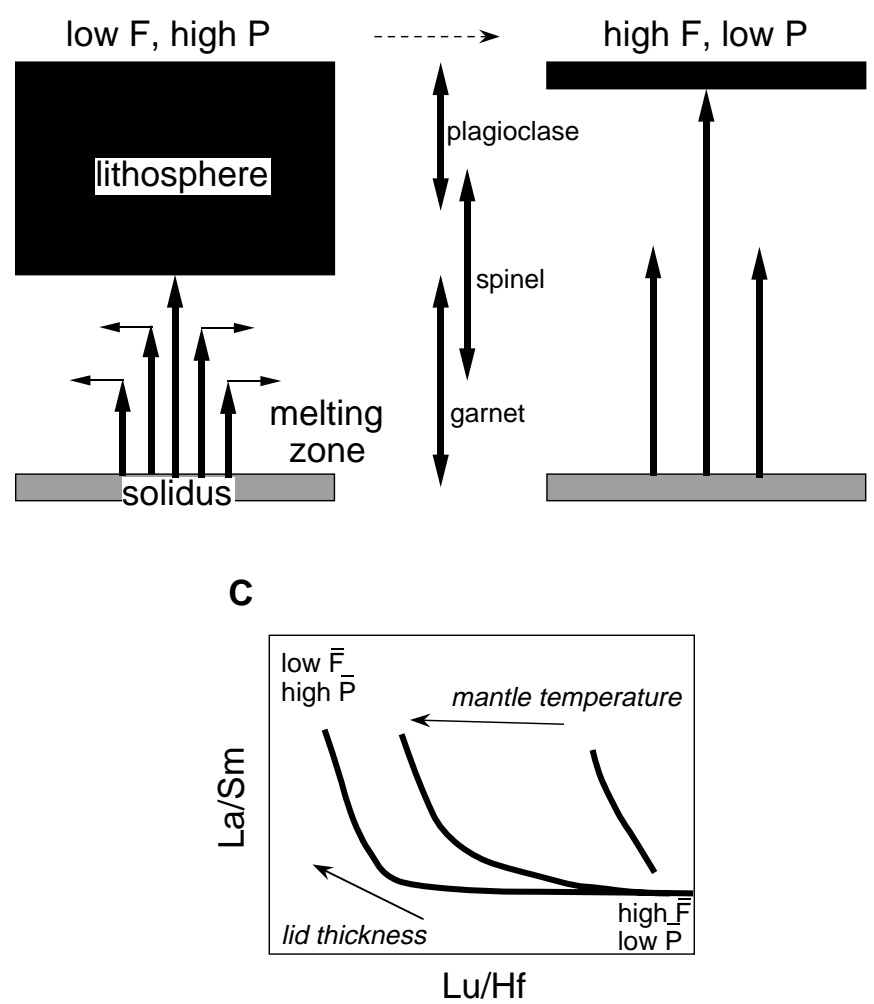

Figure 5. A. Mantle upwelling beneath a thick lithosphere melts as it rises from the solidus to the depth at which flow is deflected horizontally by the overlying lithosphere. The composition of the melts reflects generation at high mean pressures and low extents of melting. The shape of the melting zone is defined by passive upwelling and simple corner flow. B. For a thinner lithosphere, the mantle upwells further, and thus the melts are generated at lower mean pressures and high extents of melting compared with the case illustrated in (A). The double-headed arrows between (A) and (B) indicate the depth interval over which plagioclase, spinel, and garnet are stable as the aluminous phase in mantle peridotite (see Table 5). C. Schematic diagram of the $\mathrm{La} / \mathrm{Sm}$ and $\mathrm{Lu} / \mathrm{Hf}$ ratios of pooled melts generated under various conditions of mantle temperature and lid thickness.

librium melting (Shaw, 1970). The melting reaction depends on the mineral assemblage present. Table 3 gives the melting reactions used for the seven different assemblages that may be encountered during melting in this model. These melting reactions are based on experimentally determined melting reactions (Kinzler and Grove, 1992; Baker and Stolper, 1994; Kinzler, 1992). Constant mineral-melt partition coefficients for the trace elements between olivine, orthopyroxene, clinopyroxene, garnet, spinel, or plagioclase and melt are assumed (Table 4) (Green, 1994 and references therein). Melts are withdrawn completely from the matrix and accumulated with no further re-equilibration with the matrix.

In between each increment of melting, the mantle composition is revised to take into account depletion due to melting and pressuredependent phase transitions. Mantle composition is monitored by modal proportions of phases. For example, at the start of the calculation there is one unit of mantle with the proportions ol: opx: cpx: gnt:: 0.50: 0.25: 0.15: 0.10. After one increment of melting, the solid residue consists of 0.985 units of mantle with proportions 0.5047 : 0.2614: 0.1419: 0.0919. The transitions from garnet to spinel and spinel to plagioclase occur over intervals rather than at discrete pressures (Fig. 5; Table 5). This approximates the natural situation where the phase transitions are gradual due to solid solution in all of the 
phases. In the calculations, exhaustion of the aluminous phase generally occurs after about $10 \%$ melting and of clinopyroxene after about $15 \%$ melting.

Here we consider the variations on $\mathrm{Lu} / \mathrm{Hf}, \mathrm{La} / \mathrm{Sm}$, and $\mathrm{La} / \mathrm{Th}$ ratios for mantle melts as indicators of mean pressure, extent of partial melting, and mantle composition. We chose these ratios because of their systematic variations with stratigraphic height and sensitivity to the source parameters of interest. $\mathrm{La} / \mathrm{Sm}$ and $\mathrm{La} / \mathrm{Th}$ ratios in the melts depend on both extent of melting and mantle composition. The partition coefficients between mantle minerals and melt for Th are lower than those for La, which are lower than those for Sm, although all three elements are incompatible $(\mathrm{D}<1)$ in all the major silicate phases in the mantle (Table 4). Therefore, as the extent of partial melting rises, $\mathrm{La} / \mathrm{Sm}$ ratios decrease and $\mathrm{La} / \mathrm{Th}$ ratios increase in the pooled melts. $\mathrm{La} / \mathrm{Th}$ and $\mathrm{La} / \mathrm{Sm}$ ratios in the melts rapidly approach the ratios in the starting mantle as extent of melting increases. Lu, on the other hand, is highly compatible in garnet (Table 4), resulting in a strong inverse correlation between $\mathrm{Lu} / \mathrm{Hf}$ ratio and the proportion of garnet in the residual mantle. Melts produced at high mean pressures will have low $\mathrm{Lu} / \mathrm{Hf}$. Lu/Hf progressively increases as melting proceeds to shallower depths (Fig. 5).

Figure 5C illustrates schematically pooled melt compositions as a function of mean pressure $(\overline{\mathrm{P}})$ and mean extent of partial melting $(\overline{\mathrm{F}})$. The portion of the curves with large changes in $\mathrm{La} / \mathrm{Sm}$ for small changes in $\mathrm{Lu} / \mathrm{Hf}$ correspond to low extents of melting in the garnet field. Only at these low extents of melting can La and Sm be fractionated from one another to any great extent. Lu is held in the garnet, so $\mathrm{Lu} / \mathrm{Hf}$ remains low. As melting continues and garnet is exhausted or melting crosses into the spinel field, $\mathrm{Lu}$ is no longer retained in the residue, and $\mathrm{Lu} / \mathrm{Hf}$ ratios rise. At the same time, $\overrightarrow{\mathrm{F}}$ increases and the similarly incompatible elements La and Sm can no longer be effectively fractionated from each other. The $\mathrm{La} / \mathrm{Sm}$ ratio approaches a constant value (the starting mantle value). The three curves drawn in Figure $5 \mathrm{C}$ also demonstrate the effect of mantle temperature on melt compositions. Hotter mantle begins melting deeper, resulting in a greater proportion of the melting occurring in the presence of garnet, and thus, lower $\mathrm{Lu} / \mathrm{Hf}$ ratios for the melts, particularly at low extents of melting.

\section{Effects of Mantle Source Composition}

Forward modeling of mantle melting includes choosing starting mantle compositions. We can provide some constraint on the composition of mantle tapped by southeast Greenland Margin volcanism by testing a range of compositions to see which best match the observations. We began with an estimate of primitive mantle composition (PM) (Sun and McDonough, 1989; Table 6), which has nearly chondritic values for $\mathrm{La} / \mathrm{Sm}, \mathrm{La} / \mathrm{Th}$, and $\mathrm{Lu} / \mathrm{Hf}$, and progressively varied the mantle composition until the resulting melting curves yielded $\mathrm{La} /$ $\mathrm{Sm}, \mathrm{La} / \mathrm{Th}$, and $\mathrm{Lu} / \mathrm{Hf}$ values in the range of ratios displayed by the Leg 152 samples. As a starting point for constructing more depleted mantle compositions we chose the $\mathrm{Sm}, \mathrm{Lu}$, and $\mathrm{Hf}$ concentrations of an upper mantle xenolith from Jagoutz et al. (1979). This composition is depleted in $\mathrm{Sm}, \mathrm{Lu}$, and $\mathrm{Hf}$ relative to the primitive mantle estimate. From there, we adjusted the degree of depletion by picking La and Th concentrations. DM1 and DM2 (Table 6) represent the two variably depleted mantle compositions that best fit the Leg 152 data. $\mathrm{DM} 1$ and DM2 have $(\mathrm{La} / \mathrm{Sm})_{\mathrm{N}}$ ratios of 0.64 and 0.28 and $\mathrm{La} / \mathrm{Th}$ ratios of 9.4 and 21, respectively (Table 6).

Figure $6 \mathrm{~A}$ shows $\mathrm{La} / \mathrm{Sm}$ and $\mathrm{Lu} / \mathrm{Hf}$ variations in calculated melts generated by melting PM, DM1, and DM2 under the same conditions of pressure of solidus intersection equal to $25 \mathrm{kbar}$. The main effect of increasing the degree of incompatible element depletion is to shift the melting curves to lower $\mathrm{La} / \mathrm{Sm}$ values. Figure $6 \mathrm{~A}$ also shows the effect of mantle temperature on the positions of the melting curves. The curves marked DM1-30,25, and 20 represent the melting curves calculated for melting of mantle with composition DM1 with the pressure of solidus intersection at 30, 25, and $20 \mathrm{kbar}$, respectively. The higher the solidus pressure, the greater the proportion of garnet in the residue, and thus, the lower the Lu/Hf ratio in the resulting melts. The large increase in Lu/Hf between DM1-25 and DM1-20 occurs because no garnet is present at pressure less than $20 \mathrm{kbar}$ (Fig. 5; Table 5).

Figure 6B illustrates the calculated pooled melt compositions that best match the $\mathrm{La} / \mathrm{Sm}$ and $\mathrm{Lu} / \mathrm{Hf}$ variations shown by the Leg 152 samples. The calculated curve for melting of the more depleted starting mantle composition (DM2) with a solidus intersection pressure of $25 \mathrm{kbar}$ reproduces the compositional variation within units from the Site 917 upper series group 1. Site 917 upper series units in group 2, as well as the Sites 915 and 918 samples, require a less depleted starting mantle composition. Figure 6B shows the calculated melting curve for DM1, which brackets the units with the highest $(\mathrm{La} / \mathrm{Sm})_{\mathrm{N}}$ of this group. It proved impossible to relate all of the units using a single mantle composition, even by employing extremely different melting systematics.

Comparison between $(\mathrm{La} / \mathrm{Sm})_{\mathrm{N}}$ and $\mathrm{La} / \mathrm{Th}$ variations in the $\mathrm{Leg}$ 152 samples and calculated melts further confirms the need for at least two end-member mantle compositions (Fig. 7). Thorium is more incompatible than Sm (Table 4), so moderate extents of melting frac-

Table 3. Melting reaction stoichiometry for REEBOX melting model.

\begin{tabular}{llllllll}
\hline & & oliv & opx & cpx & gnt & spin & plag \\
\hline Reaction 1 & 1 liq $=$ & 0.19 & -0.50 & 0.68 & 0.63 & & \\
Reaction 2 & 1 liq $=$ & -0.015 & -0.06 & 0.695 & 0.314 & 0.065 & \\
Reaction 3 & 1 liq $=$ & -0.22 & 0.38 & 0.71 & & 0.13 & \\
Reaction 4 & 1 liq $=$ & -0.135 & 0.285 & 0.495 & & 0.065 & 0.29 \\
Reaction 5 & 1 liq = & -0.05 & 0.19 & 0.28 & & & 0.58 \\
Reaction 6 & 1 liq = & -0.25 & 0.30 & 0.95 & & & \\
Reaction 7 & 1 liq = & 0.25 & 0.75 & & & & \\
\hline
\end{tabular}

Notes: Based on Kinzler and Grove (1992), Baker and Stolper (1994), and Kinzler (1992). oliv = olivine, opx = orthopyroxene, $\mathrm{cpx}=$ clinopyroxene, gnt $=$ garnet, spin $=$ spinel, and plag = plagioclase.

Table 4. Partition coefficients (from Green, 1994) for REEBOX melting model.

\begin{tabular}{llllll}
\hline & La & Sm & Lu & Hf & Th \\
\hline Olivine & 0.00003 & 0.001 & 0.035 & 0.001 & 0.0001 \\
Orthopyroxene & 0.007 & 0.04 & 0.06 & 0.04 & 0.0001 \\
Clinopyroxene & 0.05 & 0.3 & 0.4 & 0.25 & 0.0015 \\
Garnet & 0.01 & 0.217 & 5.5 & 0.65 & 0.0015 \\
Spinel & 0.005 & 0.008 & 0.02 & 0.4 & 0.0001 \\
Plagioclase & 0.27 & 0.11 & 0.025 & 0.0001 & 0.0001 \\
\hline
\end{tabular}

Table 5. Phase transitions for REEBOX melting model.

\begin{tabular}{ll}
\hline \multicolumn{1}{c}{ Transition } & Pressure \\
\hline Garnet to spinel begins & $30 \mathrm{kbar}$ \\
Garnet to spinel complete & $20 \mathrm{kbar}$ \\
Spinel to plagioclase begins & $14 \mathrm{kbar}$ \\
Spinel to plagioclase complete & $10 \mathrm{kbar}$
\end{tabular}

Note: From Kinzler and Grove (1992), Falloon and Green (1988), and Takahashi and Kushiro (1983).

Table 6. Starting mantle compositions for REEBOX melting model.

\begin{tabular}{cccc}
\hline & $\begin{array}{c}\mathrm{PM}^{*} \\
(\mathrm{ppm})\end{array}$ & $\begin{array}{c}\mathrm{DM} 1 \\
(\mathrm{ppm})\end{array}$ & $\begin{array}{c}\mathrm{DM} 2 \\
(\mathrm{ppm})\end{array}$ \\
\hline $\mathrm{La}$ & 0.687 & 0.283 & 0.126 \\
$\mathrm{Sm}$ & 0.444 & 0.271 & 0.271 \\
$\mathrm{Lu}$ & 0.074 & 0.056 & 0.056 \\
$\mathrm{Hf}$ & 0.309 & 0.150 & 0.150 \\
$\mathrm{Th}$ & 0.085 & 0.030 & 0.006 \\
\hline
\end{tabular}

Note: *From Sun and McDonough (1989). 

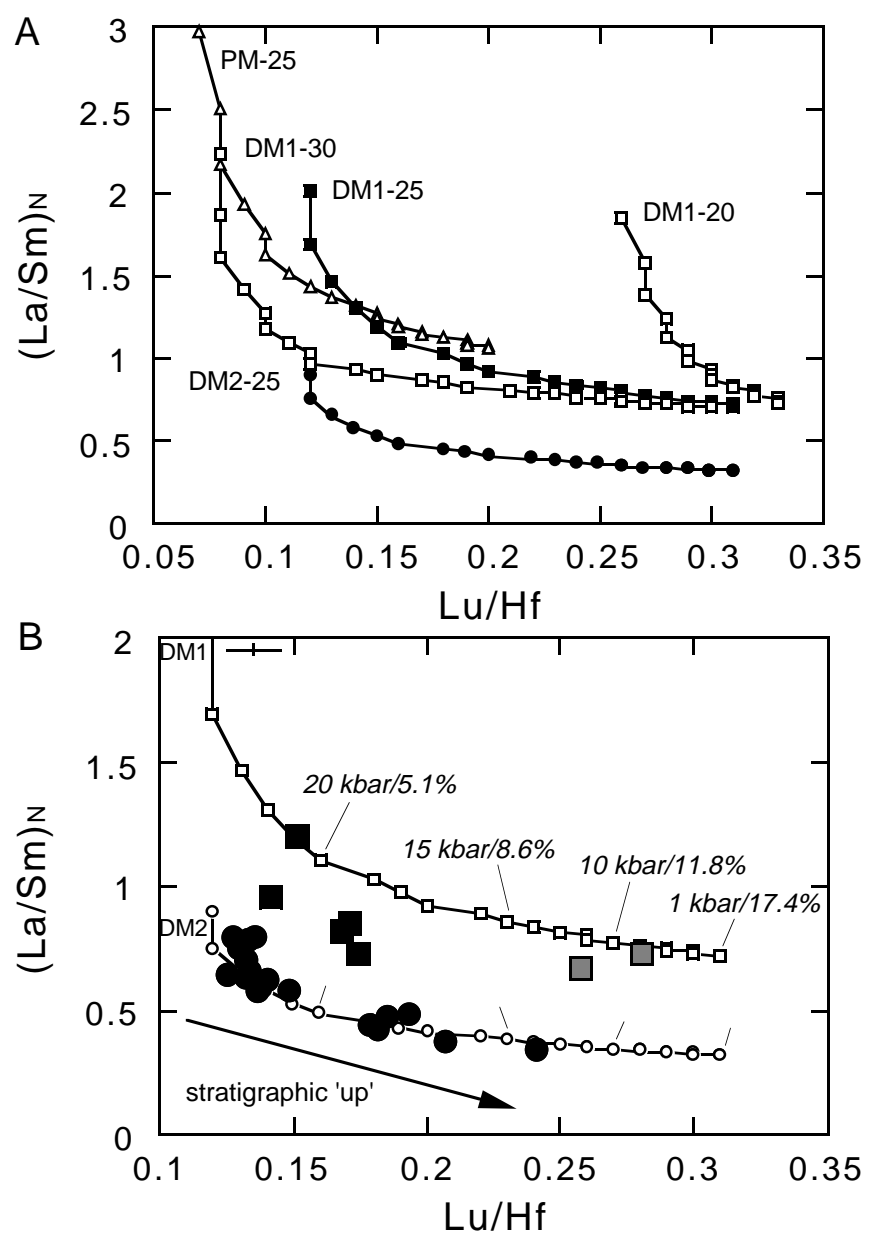

Figure 6. A. $(\mathrm{La} / \mathrm{Sm})_{\mathrm{N}}$ vs. $\mathrm{Lu} / \mathrm{Hf}$ for calculated mantle melts illustrating the effects of mantle composition, and melting systematics on melt compositions. Each curve represents the composition of pooled melts produced by progressive melting beginning at the pressure indicated by the number $(20$, 25 , or $30 \mathrm{kbar}$ ). Symbols along the curves indicate increments of $1 \mathrm{kbar}$ of decompression. PM, DM1, and DM2 refer to primitive and two different depleted mantle compositions, respectively (Table 6). Curves DM1-25 and DM2-25 are repeated in (B). B. $(\mathrm{La} / \mathrm{Sm})_{\mathrm{N}}$ vs. Lu/Hf for Leg 152 samples (Site 917 group 1 = solid circles; Site 917 group 2 = solid squares; Site 915, 918 = gray squares) compared to calculated pooled melt compositions (curves). Average error bars shown as a cross in the upper left corner of the panel. Tick marks along the curves indicate the pressure at which decompression ceases and the accumulated percent of partial melting at that level.

tionate $\mathrm{La} / \mathrm{Th}$ ratios even less than $\mathrm{La} / \mathrm{Sm}$ ratios. The model melting curves in Figure 7 show a comparatively small change in La/Th with $\mathrm{La} / \mathrm{Sm}$. However, the data show a large variation in $\mathrm{La} / \mathrm{Th}$. This suggests that the trend observed in the data is largely the result of mixing between mantle sources with $\mathrm{La} / \mathrm{Th}$ ratios of approximately 9 and approximately 21 (Fig. 7; Table 6). The Site 917 upper series group 2 units appear to be derived from a mantle source with low La/Th (Fig. 7 ), which is consistent with the relative Th enrichment noted in the calculated primary liquids for these units (Fig. 4C).

Do the constraints on mantle composition provided by this forward modeling of mantle melting provide any information on the role of the ancestral Iceland plume in southeast Greenland Margin volcanism? In Figures 7, 8, and 9 the ratios among the elements $\mathrm{Zr}, \mathrm{Nb}, \mathrm{La}$, $\mathrm{Ce}, \mathrm{Sm}, \mathrm{Th}$, and U in the Site 917 upper series and Sites 915 and 918 units are compared with those in modern Icelandic lavas and normal

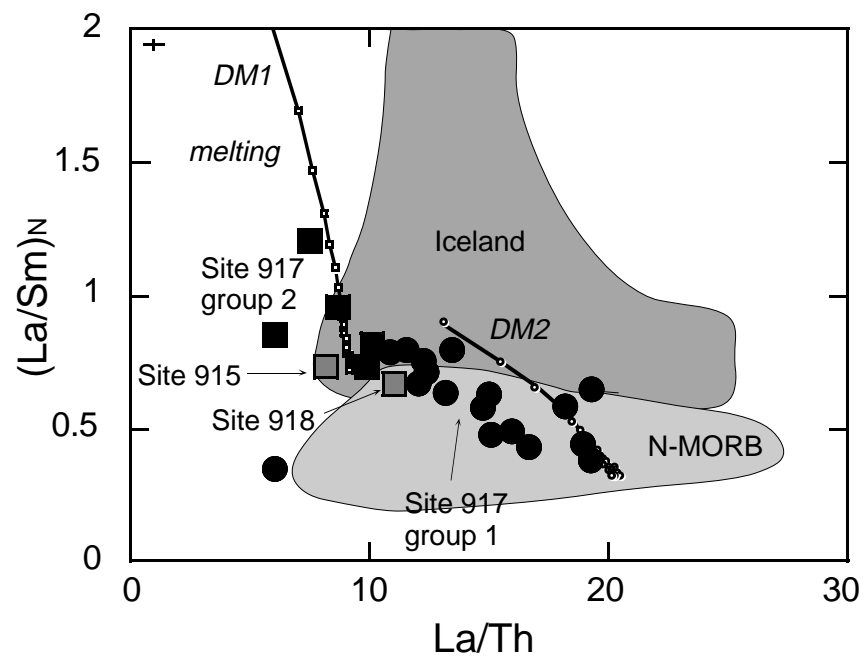

Figure 7. $(\mathrm{La} / \mathrm{Sm})_{\mathrm{N}}$ vs. La/Th for Site 917 upper series groups 1 and 2 and Sites 915 and 918 samples, modern Icelandic lavas, representative normal mid-ocean-ridge basalts, and calculated pooled melt compositions from Figure 6. Iceland data compiled from: Hemond et al. (1993), Wood et al. (1979), Meyer et al. (1985), Zindler et al. (1979), and Schilling et al. (1983). NMORB data compilation from A.D. Saunders (pers. comm., 1993). Average error bars shown by a cross in upper left corner of diagram. The sample with the lowest $(\mathrm{La} / \mathrm{Sm})_{\mathrm{N}}$ and La/Th is from Unit 14 (Sample 152-917A-12R-1, 26-31 cm, Piece 4A; Table 2) and is anomalous in many other respects (see text for discussion).

mid-ocean-ridge basalts (N-MORB). Except at very low extents of partial melting, ratios of these elements in basaltic magmas will not be significantly fractionated from the ratios in their mantle source region. $\mathrm{Zr} / \mathrm{Nb}, \mathrm{La} / \mathrm{Nb},(\mathrm{La} / \mathrm{Sm})_{\mathrm{N}}, \mathrm{La} / \mathrm{Th}$, and $\mathrm{Ce} / \mathrm{Pb}$ ratios of the Site 917 upper series group 1 lavas fall within the range exhibited by NMORB (Figs. 7-9). Incompatible element ratios of the Site 918 unit overlap the edge of the ranges shown by modern Icelandic lavas.

The incompatible element ratios of the Site 917 upper series group 2 units present a puzzle. Ratios of moderately incompatible elements, such as $\mathrm{Zr} / \mathrm{Y}$ (Fig. 2B) and Lu/Hf (Fig. 3), are coherent with ratios in Site 917 upper series group 1. $(\mathrm{La} / \mathrm{Sm})_{\mathrm{N}}$ vary from 0.7 to 1.2 and are within the range observed in modern Icelandic lavas (Fig. 7). However, ratios involving the highly incompatible elements $\mathrm{Th}, \mathrm{Pb}$, $\mathrm{U}$, and $\mathrm{Nb}$ are commonly outside the range of values observed in either N-MORB or modern Icelandic lavas. For example, $\mathrm{La} / \mathrm{Nb}$ ratios for these units vary from 2 to 3 (Fig. 8), which is higher than the range found in mid-ocean-ridge and ocean island basalts (Sun and McDonough, 1989). Depletion in Nb relative to La is a common, yet enigmatic, geochemical feature in many suites of continental flood basalt lavas (e.g., Arndt and Christensen, 1992). The relative Nb depletion in the Site 917 upper series group 2 liquids (Fig. 4C) results in both high $\mathrm{La} / \mathrm{Nb}$ and $\mathrm{Zr} / \mathrm{Nb}$. Similarly, Ce/Pb (Fig. 9) and La/Th (Fig. 7) are low due to the relative enrichments in $\mathrm{Pb}$ and $\mathrm{Th}$ in these units (Fig. $4 \mathrm{C}$ ). $\mathrm{Ce} / \mathrm{Pb}$ ratios are around 10 , which is lower than found in mid-ocean-ridge and ocean island basalts, but within the range commonly observed in island arc lavas and continental crust (Miller et al., 1994). The incompatible element ratios of the Site 915 unit are transitional between those of the Site 917 upper series group 2 units and the Site 918 unit (Figs. 7-9).

What is the explanation for these unusual patterns of enrichment and depletion of the most incompatible elements in the Site 917 upper series group 2 lavas, without accompanying anomalous behavior of the REE and other moderately incompatible elements? We explore the possibilities that contamination or mantle melting processes may be responsible. Contamination by crustal material rich in $\mathrm{Th}$ and $\mathrm{Pb}$, 


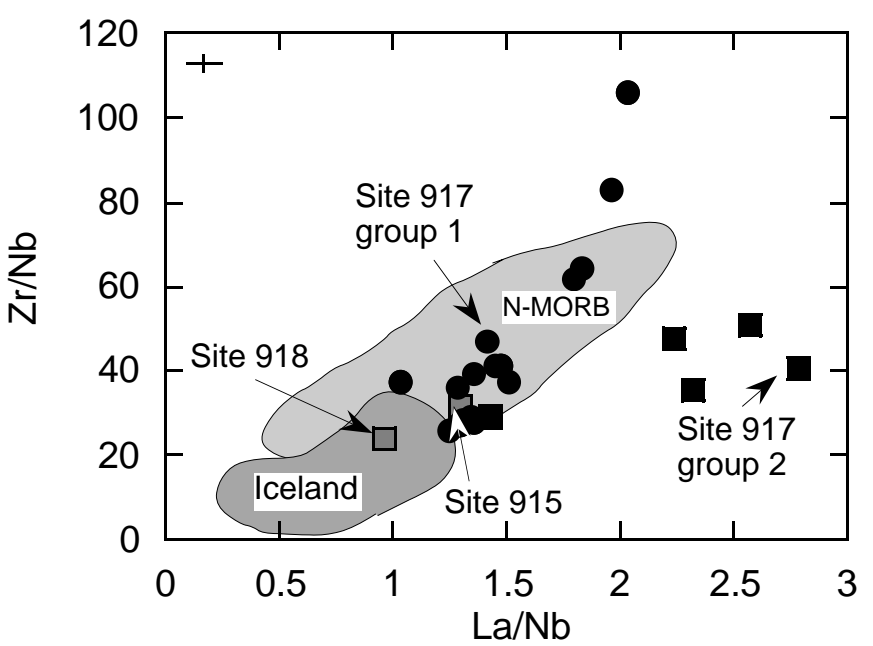

Figure 8. $\mathrm{Zr} / \mathrm{Nb}$ vs. $\mathrm{La} / \mathrm{Nb}$ for Site 917 upper series groups 1 and 2 and Sites 915 and 918 samples, modern Icelandic lavas, and representative N-MORB. References as in Figure 7. Average error bars shown as a cross in upper left corner of diagram.

but poor in $\mathrm{Nb}$ and $\mathrm{U}$ is appealing. However, $\mathrm{Sr}$ and $\mathrm{Nd}$ isotope data for the one Site 917 upper series group 2 unit analyzed do not show evidence for significant interaction with crust (Fitton et al., Chap. 29, this volume). The possibility of contamination by continental lithospheric mantle is more difficult to assess. Arndt and Christensen (1992) suggest that fractionation of $\mathrm{Nb}$ from La may occur during selective interaction between ascending magmas and metasomatized peridotite in the continental lithospheric mantle. They hypothesize that because oxide minerals dissolve at much slower rates than do silicate minerals, ascending magmas will preferentially extract LREE and other incompatible elements while $\mathrm{Nb}$ remains immobilized in the relatively unreactive oxide minerals (Arndt and Christensen, 1992). If the depletion of $U$ and enrichment of $T h$ in the continental lithospheric mantle were very old, then the $\mathrm{Pb}$ isotope systematics of the lavas may provide a test of this hypothesis.

We interpret the systematic variation in concentrations and ratios of moderately incompatible elements in the Sites 917, 915, and 918 lavas as due primarily to progressive changes in mantle melting systematics. A number of possibilities exist for using melting systematics to also account for the unusual features of the highly incompatible element ratios. Fitton et al. (Chap. 28, this volume) suggest that remelting of mantle previously melted near the axis of the plume may account for the depletions in incompatible elements in the Leg 152 lavas. Given the currently available partition coefficient data for $\mathrm{Nb}$ and $\mathrm{La}$ (Green, 1994), the residue from the first stage of melting will have a higher $\mathrm{La} / \mathrm{Nb}$ than the original mantle material because $\mathrm{Nb}$ is preferentially extracted into the melt. The second stage melt will then have higher $\mathrm{La} / \mathrm{Nb}$ than the first. However, the second stage melt should also have higher $\mathrm{La} / \mathrm{Th}$ and $\mathrm{La} / \mathrm{Ba}$ ratios than the first because both $\mathrm{Th}$ and $\mathrm{Ba}$ are more incompatible than La in mantle minerals and thus would have been preferentially extracted during the first stage of melting. This is the opposite of what is observed in the Site 917 upper series group 2 units. Another possibility is that melting occurred in the presence of an unusual residual phase. Residual Ti-oxide phases have been proposed to account for depletions of high-field strength elements in both arc and some ocean island settings (Sun and McDonough, 1989; Clague and Frey, 1982; Saunders et al., 1991). The relative depletions in $\mathrm{Nb}$ and $\mathrm{Hf}$ in the Site 917 upper series group 2 units are qualitatively consistent with the residual Ti-oxide phase hypothesis. However, the lavas do not show the relative depletions in $\mathrm{Zr}$ (Fig. 4C) or Ti (Larsen et al., Chap. 27, this volume) that are commonly associated with $\mathrm{Nb}$ depletions in arc magmas. More-

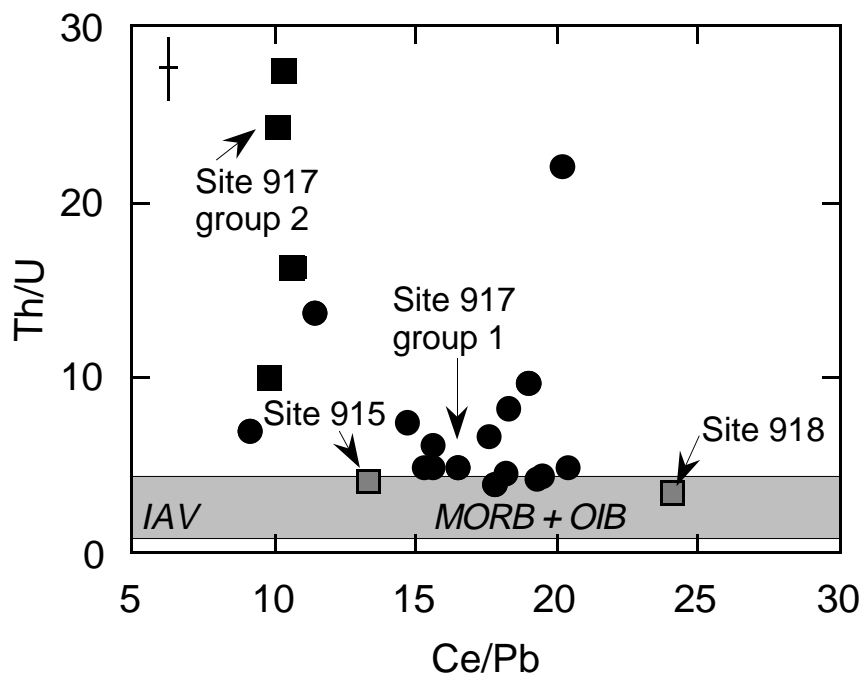

Figure 9. Th/U vs. $\mathrm{Ce} / \mathrm{Pb}$ for Site 917 upper series groups 1 and 2 and Sites 915 and 918 samples. Average error bars shown as a cross in upper left corner of diagram. Shaded field indicates the range of $\mathrm{Ce} / \mathrm{Pb}$ observed in island arc volcanics (IAV), and mid-ocean-ridge and ocean island basalts (MORB + OIB) (e.g., Miller et al., 1994; Sun and McDonough, 1989).

over, the behavior of $\mathrm{Th}, \mathrm{U}$, and $\mathrm{Pb}$ is hard to account for using a Tioxide phase. However, the partition coefficients for all these elements between Ti-oxide phases and basaltic are currently too poorly known to rule out this hypothesis. It is also possible that some other minor residual phase is the culprit. The effect of a minor residual phase would only be apparent at the moderate to low extents of partial melting (4\%-7\%; Fig. 6B) that produced the Site 917 upper series group 2 primary liquids. The minor phase would then no longer be residual at the higher extents of melting $(\sim 12 \%$; Fig. $6 \mathrm{~B})$ that produce the Site 918 magmas.

Modern Icelandic volcanism taps a geochemically heterogeneous mantle that includes both "depleted" and relatively "enriched" portions as defined by incompatible element ratios such as $(\mathrm{La} / \mathrm{Sm})_{\mathrm{N}}$ (e.g., Hemond et al., 1993; Schilling and Noe-Nygaard, 1974; Schilling et al., 1983). Given the similarity in incompatible element ratios between the Site 918 unit and modern Icelandic lavas (Figs. 7-9), and the progressive shift in incompatible element ratios from the Site 917 upper series group 2 to the Site 915 to the Site 918 lavas, we suggest that both the Sites 915 and 918 and the Site 917 upper series group 2 lavas were derived from a mantle source with composition like the depleted end of the mantle currently tapped by Icelandic volcanism (see also Fitton et al., Chap. 28, this volume). Units for group 1 of the Site 917 upper series appear not to have been derived from a mantle source region compositionally related to the Iceland geochemical anomaly, and were instead derived from mantle compositionally similar to that tapped by modern mid-ocean-ridge volcanism such as that on the Reykjanes Ridge south of the influence of the Iceland anomaly.

The stratigraphic significance of shifts in the composition of the mantle source for the lavas must be emphasized. Lavas at the base of the Site 917 upper series (group 1) appear to have N-MORB mantle as the source. Mantle compositionally similar to the modern Icelandic plume mantle begins contributing midway through eruption of the Site 917 upper series (group 2), and by the top of the upper series, is the sole mantle source. This transition in mantle composition occurs prior to the shift to fully oceanic volcanism, as defined by eruption of the main SDRS lavas. Detailed study of lavas recovered at Site 990 of ODP Leg 163, which is in the vicinity of Site 915, is needed to resolve the transition from lavas similar to those of Site 917 upper series group 2 to those similar to Site 915 and finally Site 918 lavas. 


\section{The Lid Effect}

The results of the mantle melting models suggest that lithospheric thinning played an important role in the temporal changes of the compositions of primary magmas for the Site 917 upper series and Sites 915 and 918 units. Our results imply that units at the base of the Site 917 upper series represent $4 \%-5 \%$ melts generated at pressures of greater than $20 \mathrm{kbar}$, whereas units at the top of the upper series represent approximately 10\%-12\% melts generated during decompression of mantle from a pressure of $25 \mathrm{kbar}$ to a pressure of $10 \mathrm{kbar}$ (Fig. 6B). Moreover, the inferred $\overline{\mathrm{F}}$ increases and $\overline{\mathrm{P}}$ decreases progressively with stratigraphic height in the Site 917 upper series, and the Sites 915 and 918 units, represent the largest $\overline{\mathrm{F}}$ at lowest $\overline{\mathrm{P}}$ of all the Leg 152 lavas (Fig. 6B). This progression matches the temporal evolution in melting systematics for the whole North Atlantic Tertiary volcanic province (NATVP) observed by Fram and Lesher (1993).

The Leg 152 transect provides a unique opportunity to examine the lid effect at very high temporal resolution. Fram and Lesher (1993) observed that the transition in melting systematics for basalts from the NATVP occurred between the earliest volcanic products, represented by older portions of the continental flood basalt sequences, and the SDRS basalts. They suggested that this transition reflected the shift from continental to oceanic volcanism brought about by rapid extension and disappearance of the continental lithosphere overlying the upwelling mantle. Here we have shown that the transition occurs over a very short stratigraphic interval indeed. Our modeling suggests that the lid thins from about $60 \mathrm{~km}$ to less than $25 \mathrm{~km}$ over the time interval represented by the 141-m-thick upper series at Site 917.

Are these inferences of lithospheric thinning during the time interval represented by the upper series geologically reasonable? The time interval represented by the upper series is not known precisely because none of the flows provided suitable material for Ar-Ar dating (Sinton and Duncan, this volume). However, we can estimate the time interval based on radiometric and paleomagnetic dates on units above and below the upper series. Sinton and Duncan (this volume) report an Ar-Ar age of $61.7 \pm 0.5 \mathrm{Ma}$ for a dacite unit at the base of the middle series, and there is a sedimentary unit between the middle and upper series, implying a hiatus in volcanism of unknown duration between the two series. This implies that eruption of the upper series began no earlier than $61 \mathrm{Ma}$ and probably began somewhat later. The upper series contains two immature red soil layers (in Sections 152917A-16R-1 and 20R-1; Shipboard Scientific Part, 1994), implying that the upper series was not erupted in one continuous eruptive episode. The main portions of the SDRS are interpreted to be correlated with seafloor magnetic Anomaly 24R and, thus, are approximately 55 m.y. old (Larsen, Saunders, Clift, et al., 1994). The lavas at Site 917 are clearly older than the main SDRS by a few million years, but precise dating from the magnetic anomalies has proved difficult (Larsen, Saunders, Clift, et al., 1994). Thus, we can safely assume that the upper series erupted over a time interval of less than 5 m.y. and probably less than 2 m.y.

A first-order test of our lithospheric thinning model is comparison of strain rates inferred from the model results with strain rates inferred from geologic data. We examine the simple case of extension by uniform flow (pure shear). The relationship between the layer thickness, $w$, the strain rate, $\dot{\varepsilon}$, and the time, $t$, is given by Kellogg and Turcotte (1987) as $w(t)=w_{o} e^{-\dot{\varepsilon} t}$. Our melting model yields values for $w_{o}$ and $w(t)$ of $60 \mathrm{~km}$ and $25 \mathrm{~km}$, respectively. Based on the discussion above, we conservatively assume that the upper series erupted over an interval of between 0.5 m.y. and 2.5 m.y. Calculated values for the strain rate during lithospheric extension then vary from $5.6 \times$ $10^{-14} \mathrm{~s}^{-1}$ to $1.1 \times 10^{-14} \mathrm{~s}^{-1}$. Geologically reasonable strain rates range from $10^{-13} \mathrm{~s}^{-1}$ to $10^{-15} \mathrm{~s}^{-1}$ based on finite strains observed in naturally deformed rocks (Pfiffner and Ramsay, 1982), rates of crustal deformation measured in active fault zones (Turcotte and Schubert, 1982; Suppe, 1985), and estimates of strain rates for the mantle derived from plate velocities (Turcotte and Schubert, 1982). Thus, thinning of the lithosphere from $60 \mathrm{~km}$ to $25 \mathrm{~km}$ during eruption of the upper series, as implied by our melting model, is geologically reasonable.

One further possibility we need to consider is that lateral migration of melts may have blurred the picture. The observed transition in melt compositions may represent a shift in the eruption sites rather than a thinning of the lithosphere at one location. The shift to shallower melting implied by the compositions of the upper series lavas could represent extraction of melts from mantle source regions progressively farther to the east (offshore) with time. We cannot rule out this possibility, although we find no evidence to suggest that it is more likely than the lithospheric thinning model that we propose. The volcanic sequence at Hold with Hope provides an instructive contrast to the Site 917 upper series. The Lower Series at Hold with Hope records lower mean pressures of melting than the upper series, and the transition between the two is sharp (Thirlwall et al., 1994). Thirlwall et al. (1994) interpret this as representing an abrupt shift westward (inland) in the locus of melt formation and eruption. Apparently, lavas of the Hold with Hope Lower Series had flowed significant distances westward from their eruption sites over thinned lithosphere (Thirlwall et al., 1994). Based on the example of the Hold with Hope lavas, the significant lateral change in the location of melt generation is marked by the abrupt transition in the stratigraphic record. The smooth and progressive changes in melting systematics recorded by the Site 917 upper series are more consistent with a gradual process, such as lithospheric thinning, at one location.

\section{Picrites and the Persistent Volume Problem}

The modeling presented here has some interesting implications for the development of the thick igneous crust of the SDRS. As the melting model is constructed, changes in the geochemistry of basalts must correspond to changes in melt volumes because the volume of melt produced is proportional to the length of the melting column. The modeling results indicate extents of melting of $4 \%-12 \%$ account for the geochemistry of the Site 917 upper series units (Fig. 6B). This implies that the magmas were not produced by extremely high degrees of melting - an observation that appears to be at odds with the occurrence of picrites in the succession. An explanation for this apparent contradiction is not easy to find, unless we are willing to reexamine the prevailing wisdom concerning picrites.

Classically, picrites are defined as basalts with high normative olivine contents. Bowen (1928) noted that all picrites have high abundances of olivine phenocrysts and suggested that such lavas erupt as suspensions, although they may have been wholly liquid magmas at depth. Picrite has also come to mean highly magnesian liquid formed by high degree partial melting of the mantle, usually at high pressure (e.g., Green and Ringwood, 1967; O'Hara, 1965). We suggest that the occurrence of picrites in volcanic successions is mainly a function of differentiation histories (Fram and Lesher, 1997). Basaltic magmas will retain highly magnesian, primary compositions as long as fractionation can be suppressed or avoided altogether. Fitton et al. (1995; Chap. 28, this volume) suggest that eruption of magnesian lavas in the Site 917 upper series indicates free and easy access of the magmas to the surface during final continental breakup.

The modeling presented here indicates that the Site 917 upper series magmas were generated at moderately high $\mathrm{P}$ due to the lid effect. It has long been recognized that the iron and magnesium contents of primary mantle melts increase dramatically as the mean pressure of melting rises (e.g., Jaques and Green, 1980; Langmuir and Hanson, 1980). Thus, we can at least qualitatively understand the eruption of picritic lavas at Site 917 as due to a combination of generation by high pressure melting and of suppression of fractionation - and that these picrites may indeed be formed by low to moderate extents of melting.

However, the issue of volume persists. The largest extents of partial melting inferred from our modeling of upper series and SDRS 
lava compositions are only on the order of $10 \%-12 \%$. Similar extents of partial melting are inferred for MORBs on the Reykjanes Ridge (e.g., Klein and Langmuir, 1987), yet the crustal thickness associated with the SDRS is much greater than that associated with the modern ridge. How can low to moderate extents of melting produce crust as thick as the SDRS? Zehnder et al. (1990) and Mutter et al. (1988) suggest that increased volumes of melt are produced by enhanced convection. Thermal gradients between the rifting lithosphere and the asthenosphere lead to circulation of more mantle through the melting zone than possible by simple passive upwelling. Pedersen and Skogseid (1989) provide an alternative hypothesis by suggesting that melts are pooled for a much wider region and focused under the zone of continental rupture. Explanations such as these are fundamentally different than the prevailing hypothesis in which large volumes of melt are produced by passive upwelling of anomalously hot mantle (e.g., White and McKenzie, 1989; Gill et al., 1992; White et al., 1987). Increased mantle temperature would cause melting to begin deeper and the resulting magmas to represent higher extents of melting and thus would be apparent in the geochemistry of the erupted lavas. We have certainly not resolved the problem of melt volumes, but the information contained in geochemistry of the lavas discussed in this paper provides solid constraints that must be satisfied by any model for generating the large volumes of melt.

An intriguing solution to the volume problem was recently proposed by Ribe et al. (1995). They present numerical models of a dynamically upwelling plume. Such an active upwelling entails a decoupling between mantle upwelling rate and lithospheric spreading rate. Thus, crustal thickness will not depend solely on mantle temperature, but additionally on the relative rates of spreading and upwelling. Ribe et al. (1995) suggest that the excess crustal thickness observed at Iceland can be generated by active upwelling of mantle with a temperature anomaly of only $90^{\circ} \mathrm{C}$-about half the magnitude of the anomaly proposed by White and McKenzie (1989).

\section{Implications for the Ancestral Iceland Plume}

Finally, the constraints on the thermal and compositional state of the mantle samples by southeast Greenland Margin volcanism provided by the modeling and data presented here have implications for the structure of the Iceland anomaly in the early Tertiary. We regard it significant that eruptive units derived from distinguishable mantle sources representing N-MORB and depleted Icelandic-type compositions are interfingered within the short stratigraphic interval represented by the Site 917 upper series. Furthermore, the temporal evolution in melting systematics from low to higher is apparent in magmas derived from both inferred mantle sources (e.g., Figs. 3, 4). These observations suggest a heterogeneous mantle composed of distinct compositional domains in close proximity. The stratigraphic interval with interfingering of units from distinct mantle sources appears to be followed by dominance of units extracted from a depleted Icelandictype source mantle only. This implies a local mantle structure consisting of a core of Icelandic-type mantle preceded by a zone of mixed Icelandic and N-MORB-type mantles. This view of the developing Iceland plume in the early Tertiary is similar to the model proposed by Fitton et al. (Chap. 28, this volume), but with additional detail concerning the fine structure in the margins of the anomaly that are implied by the high-resolution stratigraphic geochemical relations discussed here. Fitton et al. (Chap. 28, this volume) propose a plume composed of Icelandic mantle, which may itself be a mixture of distinct components (e.g., Hemond et al., 1993; Fitton et al., Chap. 28 , this volume), with a MORB-mantle carapace. Preliminary numerical models of development of plumes composed of compositionally and thermally buoyant mantle indicate that during lateral flow of plume material along the base of the lithosphere, a zone of mixing between plume and ambient mantle develops on the leading edge of the plume (Fram and Kellogg, 1995). At locations distal from the plume axis, this mixed zone may become extensive enough to persist for up to a few million years. The Leg 152 transect is $600-1000 \mathrm{~km}$ from proposed locations of the plume axis (Fig. 1), so such a process may be possible.

The pressure of solidus intersection derived from the modeling can be translated into a mantle temperature based on knowledge of the mantle solidus (e.g., McKenzie and Bickle, 1988; Langmuir et al., 1992). Our results suggest a pressure of 25 kbar (Fig. 6), which implies a mantle temperature of about $100^{\circ} \mathrm{C}$ greater than normal. This temperature is on the low side of the range estimated for the mantle underlying the whole North Atlantic region in the early Tertiary (Fram and Lesher, 1993), and it may reflect a real decrease in mantle temperature with distance from the plume axis. Interestingly, both mantle compositions melt under similar conditions, suggesting that the thermal anomaly is much more evenly distributed than the compositional anomaly in the mantle beneath the Leg 152 transect.

\section{ACKNOWLEDGMENTS}

Support for this research was provided by JOI/USSSP (MSF), LLNL/IGPP (CEL, MSF, and AMV), the University of California President's Postdoctoral Fellowship Program (MSF), and NSF grant EAR94-19382 (CEL). L.M. Larsen of the Geological Survey of Greenland kindly allowed us to use her collection of Leg 152 analyses. We are especially grateful to A.B. Kersting for her advice and assistance in all aspects of the analytical work at LLNL. This manuscript also benefited from our discussions with L.H. Kellogg, J.G. Fitton, and L.M. Larsen, and from thorough reviews by R.W. Kent, J.A. Brodie, and A.D. Saunders.

\section{REFERENCES}

Arndt, N.T., and Christensen, U., 1992, The role of lithospheric mantle in continental flood volcanism: thermal and geochemical constraints. $J$. Geophys. Res., 97:10967-10981.

Baker, M.B., and Stolper, E.M., 1994. Determining the composition of highpressure mantle melts using diamond aggregates. Geochim. Cosmochim. Acta, 58:2811-2827.

Bowen, N.L., 1928. The Evolution of the Igneous Rocks: New York (Dover Publ.).

Campbell, I.H., and Griffiths, R.W., 1990. Implications of mantle plume structure for the evolution of flood basalts. Earth Planet. Sci. Lett., 99:79-93.

Clague, D.A., and Frey, F.A., 1982. Petrology and trace element geochemistry of the Honolulu volcanics, Oahu: implications for the oceanic mantle below Hawaii. J. Petrol., 23:447-504.

Duncan, R.A., 1984. Age progressive volcanism in the New England seamounts and the opening of the central Atlantic Ocean. J. Geophys. Res., 89:9980-9990.

Duncan, R.A., and Richards, M.A., 1991. Hotspots, mantle plumes, flood basalts, and true polar wander. Rev. Geophys., 29:31-50.

Ellam, R.M., 1992. Lithospheric thickness as a control on basalt geochemistry. Geology, 20:153-156.

Falloon, T.J., and Green, D.H., 1988. Anhydrous partial melting of peridotite from 8 to $35 \mathrm{~kb}$ and the petrogenesis of MORB. J. Petrol., Spec. Lithosphere Iss., 379-414.

Fitton, J.G., Saunders, A.D., Larsen, L.M., Fram, M.S., Demant, A., Sinton, C., and Leg 152 Shipboard Scientific Party, 1995. Magma sources and plumbing systems during break-up of the Southeast Greenland margin: preliminary results from ODP Leg 152. J. Geol. Soc. London, 152:985990.

Fram, M.S., 1994. Petrogenesis of the Early Tertiary flood basalts of the East Greenland continental margin [Ph.D. thesis]. Columbia Univ., New York.

Fram, M.S., and Kellogg, L.H., 1995. Numerical models and geochemistry constrain the role of the Iceland plume in early Tertiary volcanism on the SE Greenland margin. Eos, 76:F692.

Fram, M.S., and Lesher, C.E., 1993. Geochemical constraints on mantle melting during creation of the North Atlantic basin. Nature, 363:712715 .

, 1997. Generation and polybaric differentiation of magmas of the East Greenland Early Tertiary flood basalts. J. Petrol., 38:231-275. 
Gill, R.C.O., Pedersen, A.K., and Larsen, J.G., 1992. Tertiary picrites in West Greenland: melting at the periphery of a plume? In Storey, B.C., Alabaster, T., and Pankhurst, R.J. (Eds.), Magmatism and the Causes of Continental Break-up. Geol. Soc. Spec. Publ. London, 68:335-348.

Gladney, E.S., and Roelandts, I., 1988. 1987 compilation of elemental concentration data for USGS BIR-1, DNC-1, and W-2. Geostand. Newsl., 112:63-118.

Green, D.H., and Ringwood, A.E., 1967. The genesis of basaltic magmas. Contrib. Mineral. Petrol., 15:103-190.

Green, T.H., 1994. Experimental studies of trace-element partitioning applicable to igneous petrogenesis-Sedona 16 years later. Chem. Geol., 117:1-36.

Hall, G.E.M., Pelchat, J.C., and Loop, J., 1990. Determination of zirconium, niobium, hafnium, and tantalum at low levels in geological materials by inductively coupled plasma mass spectrometry. J. Anal. At. Spectrom., 5:339-349.

Hemond, C., Arndt, N.T., Lichtenstein, U., Hoffman, A.W., Oskarsson, N., and Steinthorsson, S., 1993. The heterogeneous Iceland plume: Nd:Sr:O isotopes and trace element constraints. J. Geophys. Res., 98:1583315850 .

Ionov, D.A., Savoyant, L., and Dupuy, C., 1992. Application of the ICP-MS technique to trace element analysis of peridotites and their minerals. Geostand. Newsl., 16:311-315.

Jagoutz, E., Palme, H., Baddenhausen, H., Blum, K., Cendales, M., Dreibus, G., Spettel, B., Lorenz, V., and Waenke, H., 1979. The abundances of major, minor and trace elements in the Earth's mantle as derived from primitive ultramafic nodules. Proc. 10th Lunar Planet. Sci. Conf., 20312050.

Jaques, A.L., and Green, D.H., 1980. Anhydrous melting of peridotite at 0$15 \mathrm{~kb}$ pressure and the genesis of the tholeiitic basalts. Contrib. Mineral. Petrol., 73:287-310.

Jenner, G.A., Longerich, H.P., Jackson, S.E., and Fryer, B.J., 1990. ICP-MS: a powerful tool for high-precision trace-element analysis in earth sciences: evidence from analysis of selected U.S.G.S. reference samples. Chem. Geol., 83:133-148.

Jochum, K.P., Rehkämper, M., and Seufert, H.M., 1994. Trace element analysis of basalt BIR-1 by ID-SSMS, HPLC and LIMS. Geostand. Newsl., $18: 43-51$

Kellogg, L.H., and Turcotte, D.L., 1987. Homogenization of the mantle by convective mixing and diffusion. Earth Planet. Sci. Lett., 81:371-378.

Kerr, A.C., 1994. Lithospheric thinning during the evolution of continental large igneous provinces: a case study from the North Atlantic Tertiary province. Geology, 22:1027-1030.

Kinzler, R.J., 1992. Mantle melting processes at the spinel-garnet transition $(17-21 \mathrm{~Kb})$ (abst.). Eos, 73:615.

Kinzler, R.J., and Grove, T.L., 1992. Primary magmas of mid-ocean ridge basalts, 1. Experiments and methods. J. Geophys. Res., 97:6885-6906.

Klein, E.M., and Langmuir, C.H., 1987. Global correlations of ocean ridge basalt chemistry with axial depth and crustal thickness. J. Geophys. Res., 92:8089-8115.

Langmuir, C.H., and Hanson, G.N., 1980. An evaluation of major element heterogeneity in the mantle sources of basalts. Philos. Trans. R. Soc. London A, 297:383-407.

Langmuir, C.H., Klein, E.M., and Plank, T., 1992. Petrological systematics of mid-ocean ridge basalts: constraints on melt generation beneath ocean ridges. In Morgan, J.P., Blackmun, D.K., and Sinton, J.M. (Eds.), Mantle Flow and Melt Generation at Mid-Ocean Ridges. Am. Geophys. Union, Geophys. Monogr., 71:183-280.

Larsen, H.C., and Jakobsdóttir, S., 1988. Distribution, crustal properties and significance of seaward-dipping sub-basement reflectors off East Greenland. In Morton, A.C., and Parson, L.M. (Eds.), Early Tertiary Volcanism and the Opening of the Northeast Atlantic. Geol. Soc. Spec. Publ. London, 39:95-114.

Larsen, H.C., Saunders, A.D., Clift, P.D., et al., 1994. Proc. ODP, Init. Repts., 152: College Station, TX (Ocean Drilling Program).

Larsen, L.M., Pedersen, A.K., Pedersen, G.K., and Piasecki, S., 1992. Timing and duration of Early Tertiary volcanism in the North Atlantic: new evidence from West Greenland. In Storey, B.C., Alabaster, T., and Pankhurst, R.J. (Eds.), Magmatism and the Causes of Continental Breakup. Geol. Soc. Spec. Publ. London, 68:321-333.

Lawver, L.A., and Müller, R.D., 1994. Iceland hotspot track. Geology, 22:311-314.

Longhi, J., 1991. Comparative liquidus equilibria of hypersthene-normative basalts at low pressure. Am. Mineral., 76:785-800.
McKenzie, D., and Bickle, M.J., 1988. The volume and composition of melt generated by extension of the lithosphere. J. Petrol., 29:625-679.

Meyer, P.S., Sigurdsson, H., and Schilling, J.-G., 1985. Petrological and geochemical variations along Iceland's neovolcanic zones. J. Geophys. Res., 90:10043-10072.

Miller, D.M., Goldstein, S.L., and Langmuir, C.H., 1994. Cerium/lead and lead isotope ratios in arc magmas and the enrichment of lead in the continents. Nature, 368:514-520.

Mutter, J.C., Buck, W.R., and Zehnder, C.M., 1988. Convective partial melting, 1. A model for the formation of thick basaltic sequences during the initiation of spreading. J. Geophys. Res., 93:1031-1048.

O'Hara, M.J., 1965. Primary magmas and the origin of basalts. Scott. J. Geol., 1:19-40.

Pedersen, T., and Skogseid, J., 1989. Vøring Plateau volcanic margin: extension, melting, and uplift. In Eldholm, O., Thiede, J., Taylor, E., et al., Proc. ODP, Sci. Results, 104: College Station, TX (Ocean Drilling Program), 985-991.

Pfiffner, O.A., and Ramsay, J.G., 1982. Constraints of geological strain rates: arguments from finite strain states of naturally deformed rocks. J. Geophys. Res., 87:311-321.

Ribe, N.M., Christensen, U.R., and Theißing, J., 1995. The dynamics of plume-ridge interaction, 1: Ridge-centered plumes. Earth Planet. Sci. Lett., 134:155-168.

Saunders, A.D., Norry, M.J., and Tarney, J., 1991. Fluid influence on the trace element compositions of subduction zone magmas. Philos. Trans. R. Soc. London A, 335:377-392.

Schilling, J.-G., and Noe-Nygaard, A., 1974. Faeroe-Iceland plume: rare earth evidence. Earth Planet. Sci. Lett., 24:1-14.

Schilling, J.-G., Zajac, M., Evans, R., Johnston, T., White, W., Devine, J.D., and Kingsley, R., 1983. Petrologic and geochemical variations along the Mid-Atlantic ridge from $29^{\circ} \mathrm{N}$ to $73^{\circ} \mathrm{N}$. Am. J. Sci., 283:510-586.

Shaw, D.M., 1970. Trace element fractionation during anatexis. Geochim. Cosmochim. Acta, 34:237-243.

Shipboard Scientific Party, 1994. Site 917. In Larsen, H.C., Saunders, A.D., Clift, P.D., et al., Proc. ODP, Init. Repts., 152: College Station, TX (Ocean Drilling Program), 107-158.

Sun, S.-S., and McDonough, W.F., 1989. Chemical and isotopic systematics of oceanic basalts: implications for mantle composition and processes. In Saunders, A.D., and Norry, M.J. (Eds.), Magmatism in the Ocean Basins. Geol. Soc. Spec. Publ. London, 42:313-345.

Suppe, J., 1985. Principles of Structural Geology: Englewood Cliffs, NJ (Prentice-Hall).

Takahashi, E., and Kushiro, I., 1983. Melting of a dry peridotite at high pressures and temperatures and basalt magma genesis. Am. Mineral., 68:859879.

Thirlwall, M.F., Upton, B.G.J., and Jenkins, C., 1994. Interaction between continental lithosphere and the Iceland plume: $\mathrm{Sr}-\mathrm{Nd}-\mathrm{Pb}$ isotope geochemistry of Tertiary basalts, NE Greenland. J. Petrol., 35:839-879.

Turcotte, D.L., and Schubert, G., 1982. Geodynamics: Applications of Continuum Physics to Geological Problems: New York (Wiley).

Wheatley, M.R., and Rock, N.M.S., 1988. Spider: a Macintosh program to generate normalized multi-element spidergrams. Am. Mineral., 73:919921.

White, R., and McKenzie, D., 1989. Magmatism at rift zones: the generation of volcanic continental margins and flood basalts. J. Geophys. Res., 94:7685-7729.

White, R.S., Spence, G.D., Fowler, S.R., McKenzie, D.P., Westbrook, G.K., and Bowen, A.N., 1987. Magmatism at rifted continental margins. Nature, 330:439-444.

Wood, D.A., Joron, J.L., Treuil, M., Norry, M.J., and Tarney, J., 1979. Elemental and Sr isotope variations in basic lavas from Iceland and the surrounding ocean floor. Contrib. Mineral. Petrol., 70:319-339.

Zehnder, C.M., Mutter, J.C., and Buhl, P., 1990. Deep seismic and geochemical constraints on the nature of rift-induced magmatism during breakup of the North Atlantic. Tectonophysics, 173:545-565.

Zindler, A., Hart, S.R., Frey, F.A., and Jakobsson, S.P., 1979. Nd and Sr isotope ratios and rare earth element abundances in Reykjanes Peninsula basalts: evidence for mantle heterogeneity beneath Iceland. Earth Planet. Sci. Lett., 45:249-262.

Date of initial receipt: 1 December 1995

Date of acceptance: 22 May 1996

Ms 152SR-236 